\title{
PROSES MEMBENTUK PERUSAHAAN BARU DALAM PELAKSANAAN EKSPANSI PERUSAHAAN GROUP DI SEKTOR PERTAMBANGAN BATUBARA
}

\author{
Hartana \\ Kandidat Doktor, Fakultas Hukum, Universitas Gadjah Mada Yogyakarta \\ Pemerhati \& Pengamat Masalah Pertambangan \\ e-mail: hartana_palm@yahoo.com
}

\begin{abstract}
ABSTRAK
Sepuluh tahun terakhir merupakan masa pertumbuhan perusahaan pertambangan batubara di Indonesia yang sangat pesat. Hal ini dikarenakan meningkatnya permintaan batubara sebagai pemasok energi di masa mendatang sehingga membuat industri ini memiliki daya tarik yang sangat besar bagi para investor dan banyak perusahaan batubara yang mengajukan Izin Usaha Pertambangan (IUP). Pemerintah telah menetapkan proyek pembangunan melalui proyek pembangkit listrik 35.000 MW. Metode penelitian yang digunakan bersifat yuridis empiris yaitu cara prosedur yang dipergunakan untuk memecahkan masalah penelitian dengan meneliti data sekunder terlebih dahulu untuk kemudian dilanjutkan dengan mengadakan penelitian terhadap data primer di lapangan. Dalam hasil penelitian, adapun cara yang digunakan oleh perusahaan pada sektor pertambangan dalam melakukan ekspansi adalah melalui cara pembentukan perusahaan baru. Ekspansi perushaaan pada sektor pertambangan tentunya memberikan beberapa implikasi yang bisa mengarah pada timbulnya praktek monopoli dan persaingan usaha tidak sehat, mengingat bertambahnya jumlah perusahaan. Adapun produksi yang dilakukan oleh empat group batubara terbesar, masing-masing belum mencapai nilai 75\% dari produksi nasional, sehingga sesuai Undang-Undang No. 5 Tahun 1999 Pasal 4 ayat (2) ekspansi yang dilakukan oleh perusahaan group tersebut tidak terbukti berimplikasi terhadap adanya praktik monopoli dan persaingan usaha tidak sehat. Kata Kunci: pengaturan ekspansi, pelaksanaan ekspansi, pembentukan perusahaan baru.
\end{abstract}

\section{ABSTRACT}

The past ten years, coal mining industry in Indonesia develop very rapidly. Coal mining industry becomes the strong magnet for investors and coal companies who submitted for the Mining License (IUP) as a result from high demand of coal supply to be used as energy supplier in the future. The Government has set up the development project of $35.000 \mathrm{MW}$ power plant. The method for the research is juridical empirical. It is a problem solving procedure by investigating secondary data first to be able to continue with the primary data. As the result, mining companies expand their business through the new company establishment. Of course those ways of company's expansion will lead to the implication of monopoly and unfair business competition, considering the increasing numbers of new companies. However, the total production forms the top 5 coal mining group companies has not reach $75 \%$ of national production, thus, according to the Law no. 5 Year 1999 article 4 paragraph 2, the company's expansion does not implicate on the monopoly and unfair business competition.

Keywords: expansion regulation, expansion practice, the new company establishment.

\section{PENDAHULUAN}

Sepuluh tahun terakhir terdapat pertumbuhan perusahaan pertambangan batubara di Indonesia yang sangat pesat. Hal ini dikarenakan meningkatnya permintaan batubara sebagai pemasok energi di masa mendatang membuat industri ini memiliki daya tarik yang sangat besar bagi para investor. Batubara merupakan salah satu komoditas energi penting di Indonesia. Penambangannya telah berlangsung sejak masa kolonial Belanda. Penambangan batubara oleh kolonial Belanda pertama kali dilakukan di 
Pulau Kalimantan dan Pulau Sumatera yang saat ini menjadi produsen utama batubara di Indonesia. ${ }^{1}$

Peningkatan jumlah konsumsi yang sangat besar tersebut disebabkan oleh banyaknya permintaan batubara sebagai sumber energi untuk pembangkit listrik terutama guna memenuhi pembangkit listrik yang ternaung dalam program 35.000 MW. Tidak mengherankan apabila sejalan dengan itu jumlah perusahaan pertambangan batubara di Indonesia pun tumbuh pesat khususnya dalam beberapa tahun terakhir. ${ }^{2}$ Perusahaan-perusahaan yang bergerak di bidang pertambangan di Indonesia biasanya berbentuk group. Tercatat terdapat 30 group yang bergerak dalam industri pertambangan Indonesia, diantaranya adalah BUMI Plc group, ADARO group, BAYAN group, INDIKA group, BANPU group, BA group, BORN group, TANITO group, ASTRA group, SINAR MAS group dan masih banyak yang lainnya. ${ }^{3}$ Dominasi keberadaan perusahaan group dibandingkan perusahaan tunggal di Indonesia ditunjukkan oleh perusahaan-perusahaan berskala besar tidak lagi dijalankan melalui bentuk perusahaan tunggal, tetapi menggunakan konstruksi perusahaan group. $^{4}$

Perusahaan-perusahaan group tersebut terus melakukan ekspansi bisnisnya di sektor pertambangan batubara. Tentu saja tujuannya adalah untuk memperoleh laba atas investasinya dan memberikan sumbangan pada peningkatan ekonomi dan sosial lingkungan yang lebih luas. Untuk mencapai tujuannya, perusahaan-perusahaan group tersebut menghadapi persaingan yang semakin ketat dari pesaing-pesaing yang mempunyai tujuan yang sama, dengan produk yang ditawarkan serta cara-cara yang hampir sama pula.

Adapun cara yang dapat digunakan untuk membentuk perusahaan group adalah dengan melakukan merger, akuisisi atau membentuk perusahaan baru. Perusahaan-perusahaan melakukan ekspansi melalui merger, akuisisi atau membentuk perusahaan baru dengan maksud dapat mengurangi

\footnotetext{
${ }^{1}$ Arif Irwandy, Batubara Indonesia, Gramedia Pustaka Utama, Jakarta, 2014, h. 37.

2 Ibid.

3 Ibid.

${ }^{4}$ Sulistiowati, "Limited Liability dalam Limited Liability pada Konstruksi Perusahaan Kelompok Piramida", Mimbar Hukum, 2011, Volume 23, Universitas Gadjah Mada, Yogyakarta., h. 251 .
}

perusahaan pesaing atau mengurangi persaingan. Selain itu, ekspansi melalui merger, akuisisi atau membentuk perusahaan baru akan mendorong perusahaan memiliki jenis usaha yang lebih besar tanpa harus melakukannya dari awal.

Penguasaan pihak swasta terhadap industri batubara nasional mengakibatkan alokasi hasil operasi produksi tambang terhitung kecil bagi kepentingan nasional. Untuk itulah pada tanggal 12 Januari 2009 Pemerintah Indonesia menerbitkan Undang-undang No. 4 Tahun 2009 tentang Pertambangan Mineral dan Batubara untuk menggantikan Undang-Undang No. 11 Tahun 1967 tentang Ketentuan-Ketentuan Pokok Pertambangan yang dinilai sudah tidak relevan lagi untuk digunakan. Di dalam Undang-Undang No. 4 Tahun 2009 dengan jelas dikatakan bahwa sumber daya alam yang telah diambil harus diprioritaskan terlebih dahulu untuk kebutuhan industri pengolahan dalam negeri atau lebih dikenal dengan istilah Domestic Market Obligation (selanjutnya disingkat DMO).

DMO diatur secara khusus dalam Peraturan Menteri Energi dan Sumber Daya Mineral No. 34 Tahun 2009 tentang Pengutamaan Pemasokan Kebutuhan Mineral dan Batubara Untuk Kepentingan Dalam Negeri. Badan Usaha Pertambangan Mineral dan Batubara (BUPMB) yang terdiri dari pemegang Kontrak Karya (KK), Perjanjian Karya Pengusahaan Pertambangan Batubara (PKP2B), dan Izin Usaha Pertambangan (IUP) wajib memenuhi kebutuhan industri pengolahan dalam negeri. BUPMB harus menjual mineral atau batubara yang telah diproduksinya kepada Pemakai Mineral Dalam Negeri (PMDN) atau Pemakai Batubara Dalam Negeri (PBDN).

Mulai tahun 2009, Menteri Energi dan Sumber Daya Mineral mengeluarkan Keputusan Menteri mengenai Penetapan Kebutuhan dan Presentase Minimal Penjualan Batubara Untuk Kepentingan Dalam Negeri dan sesuai Keputusan Menteri Energi dan Sumber Daya Mineral No. 2805 K/30/ MEM/2015 tentang Penetapan Kebutuhan dan Presentase Minimal Penjualan Batubara Untuk Kepentingan Dalam Negeri Tahun 2015 ditetapkan bahwa perkiraan kebutuhan DMO batubara untuk tahun 2015 adalah sebesar 92.310 .000 ton atau sebesar $23,4071 \%$ dari total produksi nasional sebesar 394.367 .524 ton. Perkiraan kebutuhan 
batubara tersebut akan dialokasikan ke beberapa industri nasional yaitu PLTU, Metalurgi, Pupuk, Semen, Tekstil, Kertas dan Briket.

Melihat dinamika perkembangan perusahan group khususnya yang bergerak pada sektor batubara, hanya ada segelintir perusahaan group yang menguasai produksi batubara nasional. Kondisi demikian tidak bisa dibiarkan terus berlarut karena akan terjadi inefisiensi yang sangat besar, sehingga merugikan iklim persaingan usaha. Praktek monopoli dan persaingan usaha tidak sehat disinyalir riskan terjadi, mengingat ekspansi bisnis perusahaan-perusahaan group melalui anak-anak perusahaannya di sektor pertambangan batubara masih terus berlangsung hingga kini. Oleh karena itu, diperlukan suatu produk hukum yang dapat mencegah atau menimalisir terhadap penguasaan produksi dan pemasaran batubara oleh kelompok atau group tertentu.

Sektor pertambangan batubara rentan terjadi praktek monopoli dan persaingan usaha tidak sehat, baik dalam penguasaan areal, kepemilikan saham dan pemasaran batubara. Fenomena yang terjadi di sektor pertambangan saat ini adanya penguasaan oleh perusahaan-perusahaan berbentuk group. Indonesia belum memiliki peraturan perundang-undangan yang mengatur secara khusus mengenai perusahaan group. Kerangka pengaturan perusahaan yang tergabung dalam perusahaan group masih menggunakan pendekatan perseroan tunggal. Oleh karena itu, hingga saat ini belum ada pengakuan yuridis terhadap perusahaan group. ${ }^{5}$

\section{PERUMUSAN MASALAH}

Berdasarkan pada latar belakang di atas, maka penelitian dalam penulisan ini mengkaji berkenaan dengan proses membentuk perusahaan baru dalam pelaksanaan ekspansi perusahaan group di sektor pertambangan batubara.

\section{METODE PENELITIAN}

Penelitian ini bersifat yuridis empiris, dengan menganalisis data untuk kemudian dilanjutkan dengan mengadakan penelitian terhadap data

\footnotetext{
${ }^{5}$ Sulistiowati, Aspek Hukum dan Realitas Bisnis Perusahaan Group di Indonesia, Erlangga, Jakarta, 2010, h. 19.
}

primer di lapangan. ${ }^{6}$ Adapun jenis penelitian yang digunakan adalah Penelitian Kepustakaan dan Penelitian Lapangan. Menurut Kanneth D. Bailey istilah studi lapangan merupakan istilah yang sering digunakan bersamaan dengan istilah studi etnografi (ethnographic study atau ethnography) ${ }^{7}$. Lawrence Neuman juga menjelasakan bahwa penelitian lapangan juga sering disebut etnografi atau penelitian participant observation. ${ }^{8}$

Pengolahan analisa data dilakukan sepanjang penelitian dan dilakukan secara terus-menerus dari awal sampai akhir penelitian. Berkaitan dengan konsep tersebut, data dalam penelitian ini juga dianalisis dengan mengikuti pola analisis sejenis, yaitu mulai dari tahap observasi awal sampai pada tahap berakhirnya seluruh program tindakan sesuai dengan karakteristik dan tujuan penelitian. Analisis data merupakan proses pelacakan dan pengaturan secara sistematis transkip-transkip wawancara, catatan lapangan, dan bahan-bahan lain agar penulis dapat menyajikan temuannya. Analisis data melibatkan pengerjaan pengorganisasian, pemecahan dan sintesis data serta pencarian polapola, pengungkapan hal-hal yang penting dan penentuan apa yang dilaporkan, karena banyaknya model analisis yang diajukan oleh para pakar, maka penulis hendaknya memilih salah satu model yang dianjurkan oleh para pakar tersebut.

Penulis juga diharuskan menginterpretasikan data atau informasi berupa kata-kata atau data lain secara sistematis dan mendalam. Data yang diperoleh pada tahap awal merupakan data yang masih beranekaragam yang harus diolah guna menyimpulkan keadaan secara benar di wilayah penelitian. Tahap akhir dari analisa ini adalah dengan mengadakan pemeriksaan kebenaran data. Pemeriksaan kebenaran data dilakukan dengan cara meng-cross check setiap data yang ada. Dengan kata lain, penulis harus peka dan membuka mata dari setiap permasalahan yang terjadi. Penulis tidak boleh melihat data dari satu sudut pandang tertentu,

\footnotetext{
${ }^{6}$ Soerjono Soekanto dan Sri Mamudji, Penelitian Hukum Normatif Suatu Tinjauan Singkat, Rajawali Pers, Jakarta, 1985, h. 52 .

${ }^{7}$ Kanneth D. Bailey, Methods of Social Research, New York: a Division of Macmillan Publishing Co. Inc., 1982, h. 254.

8 W. Lawrence Neuman, Social Research Methods (Qualitative and Quantitative Approaches), Ed. 5 ${ }^{\text {th }}$, Boston: Allyn and Bacon, 2003, h. 363.
} 
tetapi harus melihat dari sudut pandang yang lainnya. Hasil akhir dari penelitan ini kemudian dirumuskan dalam sebuah laporan yang bersifat deskriptif. Dikatakan bersifat deskriptif, karena penelitian ini menggunakan metode kualitatif dan dari hasil penelitian ini diharapkan dapat menggambarkan secara menyeluruh dan sistematis mengenai asas hukum, kaidah hukum, doktrin, peraturan perundangundangan dan yurisprudensi.

\section{PEMBAHASAN}

\section{Konsep Hukum Ekspansi Perusahaan}

Pasal 1 ayat (1) Undang-Undang No. 40 Tahun 2007 tentang Perseroan Terbatas menjelaskan bahwa perusahaan (perseroan) adalah badan hukum yang merupakan persekutuan modal, didirikan berdasarkan perjanjian, melakukan kegiatan usaha dengan modal dasar yang seluruhnya terbagi dalam saham dan memenuhi persyaratan yang ditetapkan dalam undang-undang ini serta peraturan pelaksanaannya.

Pasal 2 Undang-Undang No. 40 Tahun 2007 juga menjelaskan bahwa perseroan harus mempunyai maksud dan tujuan serta kegiatan usaha yang tidak bertentangan dengan ketentuan peraturan perundangundangan, ketertiban umum, dan/atau kesusilaan.

Hal ini memberikan makna bahwa apapun jenis usahanya, perusahaan tidak boleh melakukan kegiatan yang melanggar peraturan perundangundangan. Selain itu, bagi perusahaan yang menjalankan usahanya di bidang sumber daya alam, perusahaan tersebut memiliki kewajiban tanggung jawab sosial dan lingkungan. Hal ini dijelaskan pada Pasal 74 Undang-Undang No. 40 Tahun 2007, bahwa perseroan yang menjalankan kegiatan usahanya di bidang dan/atau berkaitan dengan sumber daya alam wajib melaksanakan tanggung jawab sosial dan lingkungan.

Berbeda dengan Undang-Undang No. 40 Tahun 2007 serta Undang-Undang No. 3 Tahun 1982, Molengraaff memberikan definisi perusahaan adalah keseluruhan perbuatan yang dilakukan secara terus menerus, bertindak ke luar untuk memperoleh penghasilan, dengan cara memperdagangkan atau menyerahkan barang atau mengadakan perjanjian perdagangan. Rumusan yang dikemukakan oleh Molengraaff tersebut hanya meliputi jenis usaha dan tidak meliputi perusahaan sebagai badan usaha. ${ }^{9}$ Perusahaan menurut Molengraaff lebih menekankan kepada bidang usahanya, bukan badan usaha yang memiliki kekuatan hukum formal. Tentunya pendapat, konsep atau doktrin dari Molengraaff mengenai perusahaan tidak bisa diterima dan dijalankan di Indonesia. Bagaimanapun konsep perusahaan dan segala aktivitasnya harus mengacu kepada Undang-Undang No. 40 Tahun 2007 karena undang-undang tersebut merupakan bahan hukum primer dan mempunyai kekuatan hukum mengikat.

Perusahaan harus melakukan usaha terobosan agar kontinuitas kehidupannya dapat dipertahankan yaitu melalui investasi pengembangan usaha atau lebih sering dikenal dengan sebutan ekspansi perusahaan. Ekspansi merupakan manifestasi dari keinginan untuk mempertahankan keberadaan perusahaan dalam jangka waktu yang panjang. Perusahaan tidak didirikan dengan maksud untuk berhenti setelah mendapatkan keuntungan sementara. Ekspansi dilakukan untuk memberikan pertumbuhan bagi perusahaan. Ekspansi adalah memperbesar perusahaan baik dengan jalan mendirikan usaha baru dengan produk baru ataupun produk yang sudah ada di tempat lain ataupun juga meningkatkan produksi barang yang telah diproduksi.

Perusahaan yang ingin mempertahankan keberlangsungan hidupnya harus peka terhadap peluang dan ancaman yang ada. Hal ini dimaksudkan sebagai bagian dari upaya untuk mencapai kehidupan perusahaan yang lebih baik dengan cara memenuhi kebutuhan konsumen. Bambang Riyanto menerangkan dalam konteks ekspansi, ada dua motif utama yang mendasari suatu perusahaan melakukan ekspansi, yaitu motif ekonomi dan motif psikologis. Mengenai kedua motif tersebut diuraikan sebagai berikut: ${ }^{10}$

Pertama, Motif Ekonomi. Apabila ekspansi suatu perusahaan didasarkan pada pertimbangan untuk memperbesar atau menstabilisir laba yang diperoleh. Hal ini terjadi misalnya karena semakin besarnya permintaan terhadap produk atau jasa yang diproduksi oleh suatu perusahaan. Makin besarnya jumlah produksi yang dapat dijual, berarti semakin

\footnotetext{
${ }^{9}$ Kansil dan Cristine, Hukum Perusahaan Indonesia, Pradnya Paramita, Jakarta, 1995, h. 1-2.

10 Bambang Riyanto, Dasar-dasar Pembelanjaan Perusahaan, Edisi Keempat, BPFE, Yogyakarta, 1999, h. 231.
} 
besar kemungkinan untuk mendapatkan laba yang lebih besar, sehingga dengan demikian setiap pimpinan perusahaan mempunyai harapan dan keinginan untuk dapat selalu mengembangkan dan meluaskan perusahaan. ${ }^{11}$

Dorongan tersebut adalah wajar karena perusahaan untuk dapat mempertahankan dan bahkan mengembangkan keberadaan perusahaan haruslah memperoleh keuntungan. Keuntungan yang diperoleh perusahaan mempunyai beberapa fungsi atau kegunaan antara lain sebagai berikut: Alat pengukur prestasi perusahaan; Dapat dipergunakan untuk memenuhi kewajiban-kewajiban perusahaan; Sebagai sumber dana perusahaan.

Kedua, Motif Psikologis. Ekspansi yang dilakukan dalam kategori motif psikologis semacam ini seringkali atau bahkan tidak melakukan perhitungan ekonomis terdahulu. Ekspansi ini didasarkan pada personal ambition dari pemilik atau pimpinan perusahaan untuk memperoleh prestige dan kekuasaan yang lebih besar. Hal yang menonjol dari motif psikologis adalah lebih didorong oleh insting atau judgement berupa keberanian untuk mengambil resiko meskipun tanpa didukung oleh pertimbangan rasionalitas yang matang. Dengan demikian, ekspansi merupakan suatu bentuk perluasan usaha baik dalam meningkatkan komponen aktiva lancar, aktiva tetap atau lainnya sebagai motif yang meningkatkan nilai ekonomi maupun personal ambition dari pimpinan perusahaan untuk mencapai suatu tujuan. ${ }^{12}$

Perusahaan group memiliki peran yang semakin penting dalam kegiatan usaha di Indonesia. Perusahaan group menjadi bentuk usaha yang paling banyak dipilih oleh pelaku usaha di Indonesia. Perusahaan group adalah suatu susunan dari perusahaan-perusahaan yang secara yuridis tetap mandiri dan yang satu dengan yang lain merupakan satu kesatuan ekonomi yang dipimpin oleh perusahaan induk. ${ }^{13}$

Fenomena tentang adanya perusahaanperusahaan yang bergabung dan terikat satu sama lain dalam satu konsern tumbuh pada dasawarsa terakhir baik dalam skala nasional maupun dalam

11 Ibid.

12 Ibid.

${ }^{13}$ Emmy Pangaribuan Simanjuntak, "Hukum Perusahaan Kelompok dan Globalisasi Usaha (Concern)", Bahan Ajar Mata Kuliah Hukum Dagang Internasional, Universitas Gadjah Mada, Yogyakarta, 2008, h. 1. skala internasional. Perusahaan kelompok atau group dapat disusun secara vertikal dan horizontal. Perusahaan group disusun secara vertikal dapat dikatakan ada apabila perusahaan-perusahaan yang terkait di dalam susunan itu merupakan mata rantai dari perusahaan-perusahaan yang melakukan suatu proses produksi. Perusahaan-perusahaan itu masingmasing mengusahakan lanjutan dari usaha perusahaan lain, misalnya perusahaan pertama memulai dari bahan baku, dilanjutkan ke perusahaan lain untuk mengolah menjadi bahan setengah jadi, dilanjutkan lagi ke perusahaan lain menjadi produksi terakhir untuk konsumen dan pemasarannya diusahakan oleh perusahaan lain. Semua perusahaan yang terkait itu merupakan satu kesatuan dalam perusahaan group..$^{14}$

Perusahaan group yang disusun secara horizontal adalah perusahaan-perusahaan yang masingmasing bergerak dalam bidang-bidang usaha yang sangat beragam. Perusahaan-perusahaan yang tersusun secara terkait satu sama lain tidak hanya menangani produksi tertentu dalam arti satu jenis tertentu melainkan berbagai jenis produksi, misalnya produksi pertanian, industri, perdagangan, jasa angkutan perhotelan, bank dan asuransi. Jadi, terdapat diversifikasi usaha dan sering dikenal dengan sebutan konglomerat. ${ }^{15}$

Di dalam undang-undang, tidak diatur secara khusus tentang perusahaan kelompok ini. Dari istilah kelompok bisa diartikan bahwa di dalamnya terdapat beberapa anggota di dalam kelompok itu. Di dalam KUHPerdata BW diatur mengenai persekutuan perdata yang anggotanya terdiri dari orang-orang yang mempunyai tujuan yang sama untuk memperoleh keuntungan, dengan kewajiban masing-masing memasukkan sesuatu, baik berupa modal, uang, barang, tenaga atau keahlian yang kesemuanya itu dimaksudkan untuk tujuan memperoleh keuntungan dan membagi keuntungan tersebut kepada para anggotanya. Demikian pula dari kata kelompok, dapat digambarkan bahwa dalam perusahaan kelompok terdapat beberapa anggota yaitu beberapa perusahaan yang mempunyai tujuan yang sama memajukan perusahaannya dan memperoleh keuntungan yang hasilnya juga akan dinikmati oleh perusahaan-perusahaan yang menjadi anggotanya. Dengan demikian, perusahaan

\footnotetext{
14 Ibid.

${ }^{15}$ Ibid., h. 1-2.
} 
kelompok ini juga dapat digambarkan seperti halnya persekutuan perdata. Jikalau persekutuan perdata itu anggotanya adalah beberapa orang, sedangkan dalam perusahaan kelompok anggotanya adalah beberapa perusahaan. Dalam hal ini perusahaan kelompok dapat terjadi karena beberapa hal, antara lain: ${ }^{16}$

Pertama, Suatu perusahaan yang sudah besar dan berkembang kemudian membentuk beberapa perusahaan apakah itu merupakan cabang atau sebagai anak perusahaan. Kalau kemudian berkembang menjadi beberapa anak perusahaan maka akan terjadi perusahaan kelompok/group. Dalam hal ini, perusahaan besar sebagai perusahaan pusat atau induk. Sedangkan perusahaan-perusahaan anggotanya menjadi perusahaan anak yang terkoordinasi dalam kelompok/group perusahaan.

Kedua, Menurut Undang-Undang No. 1 Tahun 1995 tentang Perseroan Terbatas (selanjutnya disingkat UUPT), diatur mengenai penggabungan, peleburan dan pengambilalihan atau merger, konsolidasi, dan akuisisi yang kemungkinan diantara konstruksi tersebut dapat mengakibatkan terjadinya perusahaan kelompok utamanya dalam pengambilalihan. Sekalipun menurut UUPT dalam penggabungan perusahaan, perusahaan yang menggabungkan diri menjadi lebur, tetapi dalam prakteknya dapat terjadi perusahaan itu masih tetap berjalan, hanya saja secara kepemilikannya ataupun aspek manajemennya dikuasai oleh perusahaan yang menerima penggabungan. Demikian pula dalam hal terjadi peleburan dalam UUPT, peleburan terjadi apabila ada dua atau beberapa perusahaan masingmasing membubarkan diri kemudian membentuk perusahaan baru, namun dalam prakteknya dapat terjadi masing-masing perusahaan tersebut secara kenyataan masih menjalankan kegiatannya, hanya saja dari segi kepemilikannya atau manajemennya dikuasai oleh salah satu perusahaan yang baru hasil dari peleburan. Demikian pula dalam hal pengambilalihan, menurut UUPT pengambilalihan yang dimaksud adalah pengambilalihan sebagian besar saham yang biasanya terjadi pada perusahaan yang besar mengambil alih perusahaan yang lebih kecil. Dalam hal ini perusahaan yang lebih kecil

\footnotetext{
${ }^{16}$ Murjianto R., Pengantar Hukum Dagang: Aspek-Aspek Hukum Perusahaan dan Larangan Praktek Monopoli, Liberty, Yogyakarta, 2002, h. 66.
}

akan dikendalikan perusahaan besar yang menjadi perusahaan induknya.

Ketiga, Pengambilalihan karena peralihan, misalnya karena pembelian. Dalam perusahaan badan hukum dapat terjadi pembelian antar perusahaan terhadap beberapa perusahaan, atau seseorang yang membeli beberapa perusahaan untuk perusahaan yang bukan badan hukum atau menguasai permodalan pada beberapa perusahaan. Dengan sendirinya hal demikian itu akan terjadi perusahaan kelompok/ group.

Keempat, Dapat pula terjadi karena adanya kerjasama di antara beberapa perusahaan yang masing-masing bergerak dalam bidang usaha yang saling berhubungan atau kepentingan yang sama. Perusahaan kelompok yang demikian tersusun secara vertikal yaitu apabila perusahaan-perusahaan yang terkait di dalam susunan itu merupakan mata rantai dari perusahaan-perusahaan yang melakukan proses produksi. Misalnya perusahaan yang satu menghasilkan barang-barang sebagai bahan baku suatu produksi, sedangkan perusahaan lainnya mengolah bahan baku tadi dan memproduksinya menjadi barang jadi dan perusahaan lainnya sebagai perusahaan di bidang pemasaran. Namun, bisa juga terjadi antara beberapa perusahaan yang masingmasing bergerak dalam bidang usaha yang beragam atau berbeda-beda. Perusahaan kelompok yang demikian itu tersusun secara horizontal. Misalnya bidang perdagangan, industri, tranportasi, asuransi, bank, produksi barang dan lain-lain, sehingga dikenal apa yang dinamakan konglomerat.

Walupun definisi perusaahan kelompok/group tidak diatur di dalam undang-undang, meskipun begitu, dalam beberapa ketentuan teknis, dapat ditemui penjabaran definisi perusahaan group. Ketentuan teknis tersebut di antaranya adalah Pasal 1 ayat (3) Peraturan Menteri Negara Agraria/ Kepala BPN No. 2 Tahun 1999 tentang Izin Lokasi menjelaskan bahwa group perusahaan adalah dua atau lebih badan usaha yang sebagian sahamnya dimiliki oleh seorang atau oleh badan hukum yang sama baik secara langsung maupun melalui badan hukum lain, dengan jumlah atau sifat pemilikan sedemikian rupa, sehingga melalui pemilikan saham tersebut dapat langsung atau tidak langsung 
menentukan penyelenggaraan atau jalannya badan usaha. ${ }^{17}$

Definisi group atau concern juga dikemukakan oleh S.M. Bartman sebagai suatu susunan dari perusahaan-perusahaan yang secara yuridis berdiri sendiri di bawah suatu pimpinan sentral. Dari aspek ekonomi perusahaan itu tersusun menjadi satu kesatuan. ${ }^{18}$ Pada negara-negara yang belum mengatur secara khusus mengenai perusahaan group, seperti Indonesia, kerangka pengaturan perseroanperseroan yang tergabung dalam perusahaan group masih menggunakan pendekatan perseroan tunggal. Pengaturan mengenai perseroan-perseroan yang tergabung dalam perusahaan group menjadi bagian dari hukum perseroan. Peraturan perundangundangan tidak mengatur mengenai perusahaan group. Oleh karena itu, hingga saat ini belum ada pengakuan yuridis terhadap perusahaan group. ${ }^{19}$

Sementara itu, dari berbagai literatur asing dapat ditemukan berbagai macam pengertian perusahaan group. The South African Institute of Chartered Accountants (SAICA), group company is a group of companies as two or more companies that share a holding company or subsidiary relationship. A holding company in relation to the subsidiary is defined as a juristic person or undertaking that controls a subsidiary. Therefore the determination of whether a company is a holding company depends on one of the following: (1) the ability of the holding company to directly or indirectly exercise, or control the exercise of, a majority of the general voting rights at a general meeting, or; (2) the right to appoint or elect, or control the appointment or election of, directors of that company who would control a majority of the votes at a board meeting, or; (3) all the general voting rights associated with issued securities of the company are held or controlled by persons contemplated in (1) and (2). ${ }^{20}$

Dari pengertian perusahaan kelompok tersebut terdapat dua aspek yang perlu diperhatikan, yaitu

\footnotetext{
${ }^{17}$ Pasal 1 ayat (3) Peraturan Menteri Negara Agraria/Kepala BPN No. 2 Tahun 1999 tentang Izin Lokasi.

${ }^{18}$ Emmy Pangaribuan Simanjuntak, Op.Cit.

${ }^{19}$ Sulistiowati, 2010, Op.Cit., h. 19.

${ }^{20}$ The South African Institute of Chartered Accountants (SAICA), The definition of a group of companies as per the new Companies Act has changed. Diakses dari: https://www. saica.co.za/tabid/1444/itemid/1784/The-definition-of-a- group -of-companies-as- per-the.aspx. Pada tanggal 1 Juli 2017.
}

pertama, Aspek ekonomi, bahwa perusahaanperusahaan itu tersusun dalam suatu kerja sama kelompok/group bersama-sama sebagai satu kesatuan dalam mencapai tujuan ekonomi yaitu perkembangan dan keuntungan perusahaan; kedua, Aspek yuridis/hukum, bahwa masing-masing perusahaan di dalam kelompok itu secara hukum berdiri sendiri terpisah satu dengan yang lainnya, sehingga bertanggungjawab secara sendiri-sendiri terhadap pihak ketiga. ${ }^{21}$

Perusahaan kelompok/group tersebut sama halnya dengan persekutuan perdata. Pada persekutuan perdata, anggotanya adalah terdiri dari orang-orang, sedangkan perusahaan kelompok anggotanya adalah terdiri dari perusahaan-perusahaan, sehingga dalam proses pembentukannya pun tidak ada keharusan dalam bentuk formal tertentu, bahkan mungkin pihak ketiga belum tentu mengetahui bahwa suatu perusahaan merupakan anggota pada suatu kelompok perusahaan, sebagai konsekuensinya masing-masing perusahaan terhadap pihak ketiga bertanggungjawab sendiri-sendiri, sekalipun tidak menutup kemungkinan secara intern di antara anggota terikat ikut andil dalam bertanggungjawab. Dengan demikian, yang terpokok tujuan dalam perusahaan kelompok sebenarnya dari aspek ekonomi yaitu keuntungan perusahaan. ${ }^{22}$

\section{Perusahaan Baru dalam Pelaksanaan Ekspansi Perusahaan Group di Sektor Pertambangan Batubara}

Batubara merupakan salah satu komoditas energi penting di Indonesia. Penambangannya telah berlangsung sejak masa Kolonial Belanda. Penambangan batubara oleh Kolonial Belanda pertama kali dilakukan di Pulau Kalimantan dan Pulau Sumatera yang saat ini menjadi produsen utama batubara di Indonesia. Pengusahaan batubara pertama kali dilakukan di Pengaron, Kalimantan Selatan, pada tahun 1849 oleh NV Oost Borneo Maatsnhappij "Benteng Emas". Selanjutnya Belanda juga mendirikan dua perusahaan tambang batubara lain di dekat Martapura, yaitu Julia Hermina dan Delft. Pada tahun 1888, penambangan batubara dibuka di Batu Panggal, Kutai, Kalimantan Timur

\footnotetext{
${ }^{21}$ Murjianto R., Op.Cit., h. 68-69.

22 Ibid.
} 
oleh L.H. Menten. Menten juga membuka upaya eksploitasi minyak bumi pertama di wilayah Kutai. ${ }^{23}$

Pada tahun 1903, Belanda kembali mendirikan perusahaan tambang batubara di Pulau Laut, Semblimbingan, Kalimantan Selatan, yang dikenal dengan nama De Steenkolen-Maatschappij "Poeloe Loeet". Perusahaan ini memproduksi batubara hingga 80.000 ton pada tahun 1908 , sehingga menjadi salah satu daerah tambang batubara terbesar di seluruh wilayah jajahan Belanda. Pada tahun 1912, produksi tertinggi mencapai 165.000 ton. Hingga $60 \%$ batubara asal Pulau Laut diekspor ke Eropa, seperti Jerman. ${ }^{24}$

Di Pulau Sumatera, kegiatan pertambangan batubara pertama kali dilakukan di daerah Sungai Durian, Sumatera Barat, akan tetapi, usaha ini mengalami kegagalan karena kesulitan dalam hal transportasi. Pada awalnya, batubara di lokasi ini mulai diselidiki pada tahun 1858 berdasarkan catatan Ir. De Groet. Pada tahun 1867-1873, Ir. De Grave melanjutkan penyelidikan bersama Ir. R. DM. Verbeck. Hasil penyelidikan ini menghasilkan tiga lokasi batubara yang prospektif di daerah Ombilin, yaitu Sungai Durian (80.000.000 ton), Lapangan Sungai Perambah (20.000.000 ton), dan Lapangan Tanah Hitam (205.600.000 ton). ${ }^{25}$

Pada tahun 1888, kegiatan penambangan batubara Ombilin, Sawahlunto, Sumatera Barat dibuka. Kegiatan pengusahaan ini tertuang dalam Naraticle Acte pertama oleh E.L. Va Ronversy, Asisten Residen Tanah Datar selaku Notaris, antara Handrik Yakobus Pelta Schemuring (pemegang konsesi) dan Laras Silungkang Djaar Soetan Pamuncak (mewakili rakyat). Di nota perjanjian juga dijelaskan pembangunan Pelabuhan Teluk Bayur dan jalan kereta api dari Teluk Bayur ke Padang Panjang hingga Sawahlunto. Pembangunan kedua penunjungan penambangan ini dilakukan tahun 1888 hingga 1893. Produksi pertama dimulai pada Oktober 1892 sebanyak 48.000 ton pada tahun itu. Pada tahun 1930, Sawahlunto mencapai produksi batubara tertinggi pertamanya, yaitu 624.212 ton. ${ }^{26}$

\footnotetext{
${ }^{23}$ Arif Irwandy, Batubara Indonesia, Gramedia Pustaka Utama, Jakarta, 2014, h. 37.

${ }^{24}$ Ibid., h. 38.

${ }^{25}$ Ibid.

${ }^{26}$ Ibid.
}

Kegiatan penyelidikan batubara terus dilanjutkan. Penyelidikan batubara pada 1915-1918 di Sumatera Selatan menghasilkan sumberdaya dan cadangan batubara baru. Pada tahun 1919, Belanda membuka penambangan batubara di Tanjung Enim dengan metode penambangan terbuka di tambang Air Laya. Pada tahun 1923-1940, penambangan dilakukan dengan metode penambangan bawah tanah. Pemenuhan kepentingan komersial dilakukan mulai tahun 1938 oleh penambangan batubara Bukit Asam, yaitu pada Air Laya untuk batubara jenis bituminous dan Suban untuk batubara jenis semi antrasit. Pada tahun 1950, Pemerintah Repuplik Indonesia mengesahkan pembentukan Perusahaan Negara Tambang Arang Bukit Asam (PN TABA) seiring berakhirnya kekuasaan pemerintah Kolonial Belanda. $^{27}$

Indonesia merupakan negara yang memiliki cadangan batubara hanya 0,6\% dari cadangan batubara dunia, yaitu sekitar 5,229 miliar ton. Cadangan itu terdiri dari batubara peringkat rendah dengan nilai kalori $<5.700 \mathrm{kal} / \mathrm{g}$ (low rank coal) yang mendominasi dan batubara peringkat tinggi dengan nilai kalori $>5.700 \mathrm{kal} / \mathrm{g}$ (high rank coal).$^{28}$

Bedasarkan SNI 5015-2011, batubara Indonesia dikelompokkan menjadi: Pertama, Batubara Kalori Rendah, yaitu jenis batubara yang paling rendah peringkatnya, bersifat lunak-keras, mudah diremas, mengandung kadar air tinggi (10-70\%), memperlihatkan struktur kayu, nilai kalorinya kurang dari 5100 kal/gr (adb). Kedua, Batubara Kalori Sedang, yaitu jenis batubara yang peringkatnya lebih tinggi daripada batubara kalori rendah, bersifat lebih keras, mudah diremas-tidak bisa diremas, kadar air relatif lebih rendah, umumnya struktur kayu masih tampak, nilai kalori 5100-6100 kal/gr (adb). Ketiga, Batubara Kalori Tinggi, adalah jenis batubara yang peringkatnya lebih tinggi lagi, kadar air relatif lebih rendah dibandingkan batubara kalori sedang, umumnya struktur kayu tidak tampak, nilai kalorinya 6100-7100 kal/gr (adb). Keempat, Batubara Kalori Sangat Tinggi, adalah jenis batubara dengan peringkat paling tinggi, umumnya dipengaruhi intrusi ataupun struktur lainnya, kadar air sangat rendah, nilai kalorinya lebih dari 7100 kal/gr (adb). Kelas

\footnotetext{
27 Ibid.

${ }^{28}$ Ibid., h. 54.
} 
kalori ini dibuat untuk membatasi batubara kalori tinggi. ${ }^{29}$

Perhitungan sumber daya dan cadangan batubara sering kali mengalami kerancuan. Di Indonesia, acuan penetapan sumber daya dan cadangan diatur dalam Standar Nasional Indonesia (SNI). Akan tetapi, dalam prakteknya, sumber daya dan cadangan batubara lebih banyak mengikuti Australian Guidelines for Estimating and Reporting of Inventory Coal, Coal Resources, and Coal Reserves 2003 ed. ${ }^{30}$

Sumberdaya batubara adalah bagian dari endapan batubara dalam bentuk dan kuantitas tertentu serta mempunyai prospek beralasan yang memungkinkan untuk ditambang secara ekonomis. Lokasi, kualitas, kuantitas karakteristik geologi dan kemenerusan dari lapisan batubara yang telah diketahui, diperkirakan atau diinterpretasikan dari bukti geologi tertentu. Sumberdaya batubara dibagi sesuai dengan tingkat kepercayaan geologi ke dalam kategori tereka, tertunjuk, dan terukur. ${ }^{31}$

Dalam SNI 5015-2011, klasifikasi sumberdaya adalah sebagai berikut: pertama, Sumberdaya hipotetik adalah sumberdaya yang kuantitas dan kualitasnya diperoleh dari tahap penyelidikan Survei Tinjau; kedua, Sumberdaya tereka adalah bagian dari total estimasi sumberdaya batubara yang kualitas dan kuantitasnya hanya dapat diperkirakan dengan tingkat kepercayaan yang rendah. Titik informasi yang mungkin didukung oleh data pendukung tidak cukup untuk membuktikan kemenerusan lapisan batubara dan/atau kualitasnya. Estimasi dari kategori kepercayaan ini dapat berubah secara berarti dengan eksplorasi lanjut; ketiga, Sumberdaya tertunjuk adalah bagian dari total sumberdaya batubara yang kualitas dan kuantitasnya dapat diperkirakan dengan tingkat kepercayaan yang masuk akal, didasarkan pada informasi yang didapatkan dari titik-titik pengamatan yang mungkin didukung oleh data pendukung. Titik informasi yang ada cukup untuk menginterpretasikan kemenerusan lapisan batubara, tetapi tidak cukup untuk membuktikan kemenerusan lapisan batubara dan/atau kualitasnya; keempat, Sumberdaya terukur adalah bagian dari total sumberdaya batubara

\footnotetext{
${ }^{29}$ Pusat Sumber Daya Mineral Batubara dan Panas Bumi. Executive Summary Pemutakhiran Data dan Neraca Sumber Daya Energi Tahun 2015, h. 3-4.

${ }^{30}$ Ibid.

${ }^{31}$ Ibid., h. 7.
}

yang kualitas dan kuantitasnya dapat diperkirakan dengan tingkat kepercayaan tinggi, didasarkan pada informasi yang didapat dari titik-titik pengamatan yang diperkuat dengan data-data pendukung. Titiktitik pengamatan jaraknya cukup berdekatan untuk membuktikan kemenerusan lapisan batubara dan/atau kualitasnya. $^{32}$

Sementara itu, cadangan batubara, yaitu bagian dari sumberdaya batubara tertunjuk dan terukur yang dapat ditambang secara ekonomis. Estimasi cadangan batubara harus memasukkan perhitungan dilution dan losses yang muncul pada saat batubara ditambang. Penentuan cadangan secara tepat telah dilaksanakan yang mungkin termasuk studi kelayakan. Penentuan tersebut harus telah mempertimbangkan semua faktorfaktor yang berkaitan seperti metode penambangan, ekonomi, pemasaran, legal, lingkungan, sosial, dan peraturan pemerintah. Penentuan ini harus dapat memperlihatkan bahwa pada saat laporan dibuat, penambangan ekonomis dapat ditentukan secara memungkinkan. ${ }^{33}$

Cadangan batubara dibagi sesuai dengan tingkat kepercayaannya ke dalam cadangan terkira dan terbukti. Definisi masing-masing istilah sesuai dengan SNI 5015:2011 sebagai berikut: pertama, Cadangan batubara terkira adalah bagian dari sumberdaya batubara tertunjuk yang dapat ditambang secara ekonomis setelah faktor-faktor penyesuai terkait diterapkan, dapat juga sebagai bagian dari sumberdaya batubara terukur yang dapat ditambang secara ekonomis, tetapi ada ketidakpastian pada salah satu atau semua faktor penyesuai yang terkait diterapkan; kedua, Cadangan batubara terbukti adalah bagian yang dapat ditambang secara ekonomis dari sumberdaya batubara terukur setelah faktor-faktor penyesuai yang terkait diterapkan. ${ }^{34}$

Hasil perhitungan keseluruhanmenunjukkan bahwa sumberdaya batubara Indonesia sampai dengan tahun 2015 ini adalah sebesar 126.609,34 juta ton batubara, sedangkan cadangan batubara sebesar 32.263,68 juta ton, sebagaimana dalam Tabel 1.35

Apabila dibandingkan dengan neraca tahun 2014 terdapat kenaikan sumberdaya batubara sebesar $1.812,60$ juta ton, begitu juga dengan cadangan

\footnotetext{
${ }^{32}$ Ibid., h. 7-8.

${ }^{33}$ Ibid., h. 8.

34 Ibid.

${ }^{35}$ Ibid., h. 10.
} 
Tabel 1. Kualitas, Sumberdaya, dan Cadangan Batubara Indonesia Tahun 2015

\begin{tabular}{lrrrrrrrrr}
\hline \multirow{2}{*}{ Kualitas } & \multicolumn{4}{c}{ Sumber Daya (Juta Ton) } & \multicolumn{1}{c}{ Jumlah } & \multicolumn{3}{c}{ Cadangan (Juta Ton) } \\
\cline { 2 - 10 } & Hipotetik & \multicolumn{1}{c}{ Tereka } & Tertunjuk & \multicolumn{1}{c}{ Terukur } & \multicolumn{1}{c}{ Total } & \multicolumn{1}{c}{ \% } & \multicolumn{1}{c}{ Terkira } & Terbukti & \multicolumn{1}{c}{ Total } \\
\hline Kalori Rendah & $1.978,83$ & $9.650,04$ & $10.432,15$ & $12.258,65$ & $34.319,67$ & 27,11 & $6.203,69$ & $3.271,78$ & $9.475,47$ \\
Kalori Sedang & $16.882,22$ & $22.413,42$ & $17.441,12$ & $24.286,35$ & $81.023,10$ & 63,99 & $16.485,65$ & $3.858,21$ & $20.343,86$ \\
Kalori Tinggi & 889,19 & $2.804,47$ & $2.186,22$ & $3.243,11$ & $9.112,99$ & 7,21 & 545,20 & 974,33 & $1.519,53$ \\
Kalori Sangat Tinggi & 13,61 & $1.276,46$ & 394,02 & 459,49 & $2.143,58$ & 1,69 & 761,51 & 163,31 & 924,82 \\
\hline \multicolumn{1}{c}{ TOTAL } & $\mathbf{1 9 . 7 6 3 , 8 4}$ & $\mathbf{3 6 . 1 4 4 , 3 9}$ & $\mathbf{3 0 . 4 5 3 , 5 1}$ & $\mathbf{4 0 . 2 4 7 , 6 0}$ & $\mathbf{1 2 . 6 6 0 9 , 3 4}$ & $\mathbf{1 0 0 , 0 0}$ & $\mathbf{2 3 . 9 9 6 , 0 5}$ & $\mathbf{8 . 2 6 7 , 6 3}$ & $\mathbf{3 2 . 2 6 3 , 6 8}$ \\
\hline
\end{tabular}

\section{Catatan:}

1. Kualitas berdasarkan kelas nilai kalori

(Keppres No. 13 Tahun 2000 diperbaharui dengan PP No. 45 Tahun 2003)

a. Kalori Rendah $<5100 \mathrm{kal} / \mathrm{gr}$

b. Kalori Sedang $5100-6100 \mathrm{kal} / \mathrm{gr}$

c. Kalori Tinggi $>6100-7100 \mathrm{kal} / \mathrm{gr}$

d. Kalori Sangat Tinggi $>7100 \mathrm{kal} / \mathrm{gr}$
2. Kelas sumber daya batubara

a. Terukur

b. Tertunjuk

c. Tereka

d. Hipotetik

Sumber: Pusat Sumber Daya Mineral Batubara dan Panas Bumi

Executive Summary Pemutakhiran Data dan Neraca Sumber Daya Energi Tahun 2015

batubara pada tahun ini mengalami penurunan sebanyak 121,06 juta ton. Hasil perhitungan keseluruhan menunjukkan bahwa sumberdaya batubara Indonesia sampai dengan tahun 2014 ini adalah sebesar $124.796,74$ juta ton batubara, sedangkan cadangan batubara sebesar $32.384,74$ juta ton. Penurunan jumlah sumberdaya dan cadangan ini dikarenakan melemahnya nilai batubara di pasar dunia, sehingga banyak perusahaan yang menghentikan kegiatan eksplorasi dan produksi batubara karena nilai jual batubara tidak dapat menutupi biaya produksi, sebagaimana Gambar 1 .

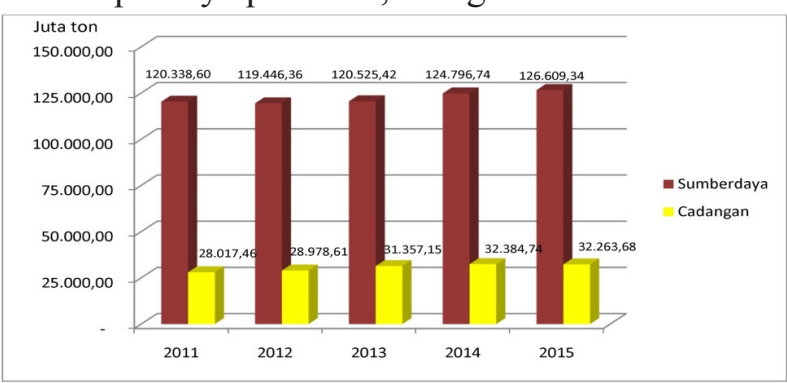

Gambar 1. Grafik Perubahan Nilai Sumberdaya dan Cadangan Batubara Tahun 2011-2015

Sumber: Pusat Sumber Daya Mineral Batubara dan Panas Bumi. Executive Summary Pemutakhiran Data dan Neraca Sumber Daya Energi Tahun 2015

Sumberdaya dan cadangan batubara per provinsi di Indonesia tahun 2015 adalah sebagaimana dalam Tabel 2. Saat ini, batubara hasil penambangan diarahkan untuk meningkatkan ketersediaan sumber daya energi alternatif. Seperti diketahui, batubara termasuk kategori barang tambang strategis. Hal ini dikarenakan batubara dijadikan energi alternatif untuk menggantikan energi minyak bumi yang cadangannya mulai berkurang. Permintaan batubara dalam negeri relatif lebih kecil dibandingkan dengan potensi pasar ekspor. ${ }^{36}$ Berdasarkan amanat Kebijakan Energi Nasional, diharapkan akan terwujud energy mix yang optimal. Salah satu tujuannya adalah peningkatan konsumsi batubara dalam negeri untuk menjadi lebih dari $35 \%$ pada tahun $2025 .{ }^{37}$ Menurut Kementerian Energi dan Sumber Daya Mineral Republik Indonesia pada awal tahun 2014, arah dari Kebijakan Energi Nasional ke depan, ketergantungan terhadap minyak bumi pelan-pelan dikurangi yang sampai saat ini mencapai $50 \%$ akan dikurangi menjadi 22\% lebih di tahun 2025. Batubara akan naik perannya dari 20 -an $\%$ menjadi $30-a n \%$. Angka persisnya akan ada di Kebijakan Energi Nasional. ${ }^{38}$

Pemerintah secara tegas mengeluarkan Peraturan Pemerintah No. 23 Tahun 2010 tentang Pelaksanaan Kegiatan Usaha Pertambangan Mineral dan Batubara. Pada Pasal 84 ayat (1) menyatakan Pemegang IUP Operasi Produksi dan IUPK Operasi Produksi harus mengutamakan kebutuhan mineral dan/atau batubara untuk kepentingan dalam negeri. ${ }^{39}$

Pada tahun 2013, Kementerian ESDM telah menentukan jumlah kebutuhan minimal batubara untuk PLTU, yaitu sebesar 49,29 juta ton atau $66,32 \%$

\footnotetext{
${ }^{36}$ Ibid., h. 73.

37 Ibid., h. 148.

38 Ibid.

39 Ibid., h. 149
} 
Tabel 2. Sumber Daya dan Cadangan Batubara Per Provinsi Tahun 2015

\begin{tabular}{|c|c|c|c|c|c|c|c|c|c|c|}
\hline \multirow{2}{*}{ No. } & \multirow{2}{*}{ Pulau } & \multirow{2}{*}{ Provinsi } & \multicolumn{5}{|c|}{ Sumberdaya (Juta Ton) } & \multicolumn{3}{|c|}{ Cadangan (Juta Ton) } \\
\hline & & & Hipotetik & Tereka & Tertunjuk & Terukur & Total & Terkira & Terbukti & Total \\
\hline 1. & JAWA & Banten & 5,47 & 5,75 & 4,86 & 2,72 & 18,80 & 0,00 & 0,00 & 0,00 \\
\hline 2. & & Jawa Tengah & 0,00 & 0,82 & 0,00 & 0,00 & 0,82 & 0,00 & 0,00 & 0,00 \\
\hline 3. & & Jawa Timur & 0,00 & 0,08 & 0,00 & 0,00 & 0,08 & 0,00 & 0,00 & 0,00 \\
\hline 4. & SUMATERA & Aceh & 0,00 & 346,35 & 13,89 & 90,40 & 450,64 & 0,00 & 0,00 & 0,00 \\
\hline 5. & & Sumatera Utara & 0,25 & 7,00 & 0,00 & 19,97 & 27,22 & 0,00 & 0,00 & 0,00 \\
\hline 6. & & Riau & 12,79 & 243,12 & 643,82 & 900,34 & $1.800,07$ & 54,49 & 633,43 & 687,83 \\
\hline 7. & & Sumatera Barat & 20,41 & 294,50 & 231,16 & 249,45 & 795,52 & 0,00 & 158,43 & 158,43 \\
\hline 8. & & Jambi & 603,71 & $1.100,30$ & 670,88 & 361,82 & $2.746,70$ & 122,17 & 118,58 & 240,75 \\
\hline 9. & & Bengkulu & 0,00 & 2,12 & 118,81 & 71,14 & 192,07 & 0,00 & 18,95 & 18,95 \\
\hline 10. & & Sumatera Selatan & $12.633,17$ & $13.161,57$ & $15.001,00$ & $11.106,17$ & $51.901,93$ & $10.134,43$ & $2.140,29$ & $12.274,72$ \\
\hline 11. & & Lampung & 0,00 & 106,95 & 0,00 & 0,94 & 107,89 & 0,00 & 0,00 & 0,00 \\
\hline 12. & KALIMANTAN & Kalimantan Barat & 2,26 & 477,59 & 6,85 & 4,70 & 491,50 & 0,00 & 0,00 & 0,00 \\
\hline 13. & & Kalimantan Tengah & 222,24 & $1.952,19$ & 883,86 & $1.047,20$ & $4.105,48$ & 284,53 & 486,73 & 771,26 \\
\hline 14. & & Kalimantan Selatan & 0,00 & $6.050,60$ & $3.461,10$ & $4.945,92$ & $14.457,62$ & $1.300,59$ & $2.354,54$ & $3.655,13$ \\
\hline 15. & & Kalimantan Timur & $6.088,84$ & $11.623,63$ & $8,807.33$ & $20.543,66$ & $47.063,46$ & $11.793,92$ & $1.968,40$ & $13.762,39$ \\
\hline 16. & & Kalimantan Utara & 65,62 & 660,81 & 480,27 & 850,09 & $2.056,79$ & 305,86 & 388,31 & 694,17 \\
\hline 17. & SULAWESI & Sulawesi Selatan & 0,00 & 48,81 & 129,68 & 53,09 & 231,58 & 0,06 & 0,06 & 0,12 \\
\hline 18. & & Sulawesi Tengah & 0,00 & 17,11 & 0,00 & 0,00 & 17,11 & 0,00 & 0,00 & 0,00 \\
\hline 19. & MALUKU & Maluku Utara & 8,22 & 0,00 & 0,00 & 0,00 & 8,22 & 0,00 & 0,00 & 0,00 \\
\hline 20. & PAPUA & Papua Barat & 93,66 & 32,82 & 0,00 & 0,00 & 126,48 & 0,00 & 0,00 & 0,00 \\
\hline 21. & & Papua & 7,20 & 2,16 & 0,00 & 0,00 & 9,36 & 0,00 & 0,00 & 0,00 \\
\hline \multicolumn{3}{|c|}{ TOTAL INDONESIA } & $19.763,84$ & 36.144 .39 & 30.453 .51 & 40.247 .60 & 126.609 .05 & $23.996,05$ & $8.267,63$ & $32.263,68$ \\
\hline
\end{tabular}

Sumber: Pusat Sumber Daya Mineral Batubara dan Panas Bumi

Executive Summary Pemutakhiran Data dan Neraca Sumber Daya Energi Tahun 2015

dari kebutuhan batubara dalam negeri. Kebutuhan batubara ini akan meningkat bila program percepatan PLTU 10.000 MW tahap pertama telah selesai dan mulai beroperasi. Berdasarkan Peraturan Pemerintah No. 71 Tahun 2006, pada program 10.000 MW tahap pertama bahan bakar yang digunakan PLTU adalah batubara rank rendah. Hal ini akan berimbas pada peningkatan permintaan batubara tipe ini di pasar nasional. Selain itu, kondisi ini juga didukung dengan pertumbuhan energi listrik nasional yang terus meningkat $6,8 \%$ setiap tahun dan adanya program diversifikasi energi dalam energy mix nasional pada tahun 2015. ${ }^{40}$

Keadaan yang demikian itu lantas banyak mengundang investor untuk berinvestasi di sektor pertambangan batubara. Biasanya perusahaan yang berinvestasi di sektor pertambangan batubara adalah perusahaan group. Tentu saja tujuannya adalah untuk memperoleh laba atas investasinya. Perusahaan tersebut terus melakukan ekspansi. Ekspansi ini dilakukan untuk menghadapi persaingan yang

\footnotetext{
${ }^{40}$ Ibid., h. 150.
}

semakin ketat dari pesaing-pesaing yang mempunyai tujuan yang sama, dengan produk yang ditawarkan serta cara-cara yang hampir sama pula. Dalam kondisi pasar yang seperti itu mengakibatkan adanya tuntutan bagi perusahaan untuk terus mengembangkan inovasi, memperbaiki kinerjanya, dan melakukan perluasan usaha agar dapat terus bertahan dan bersaing. Adapun banyak cara yang dilakukan oleh perusahaan group untuk melakukan ekspansi yaitu dengan cara membentuk perusahaan baru.

Dalam sektor pertambangan batubara, perusahaan harus memiliki Izin Usaha Pertambangan (IUP) dalam melaksanakan usahanya. Berdasarkan UndangUndang No. 4 Tahun 2009 tentang Pertambangan Mineral dan Batubara, IUP terbagi menjadi 2 (dua) yaitu, IUP Eksplorasi dan IUP Operasi Produksi.

Pertama, IUP Eksplorasi adalah izin usaha yang diberikan untuk melakukan tahapan kegiatan penyelidikan umum, eksplorasi, dan studi kelayakan pertambangan. IUP diberikan oleh: Bupati/Walikota apabila Wilayah Izin Usaha Pertambangan (WIUP) berada di dalam satu wilayah kabupaten/kota; 
Gubernur apabila WIUP berada pada lintas wilayah kabupaten/kota dalam 1 (satu) provinsi setelah mendapatkan rekomendasi dari Bupati/Walikota setempat sesuai dengan ketentuan peraturan perundang-undangan; dan Menteri apabila WIUP berada pada lintas wilayah provinsi setelah mendapatkan rekomendasi dari Gubernur dan Bupati/ Walikota setempat sesuai dengan ketentuan peraturan perundang-undangan.

Akan tetapi Berdasarkan Undang-Undang No. 23 Tahun 2014 tentang Pemerintah Daerah dan Peraturan Pemerintah Pengganti Undang-Undang (PERPPU) No. 2 Tahun 2014, Bupati/Walikota tidak lagi mempunyai kewenangan untuk menerbitkan Izin Usaha Pertambangan (IUP) di daerahnya. Kewenangan untuk menerbitkan IUP kini menjadi milik Pemerintah Provinsi, dalam hal ini Gubernur. Apabila WIUP berada pada lintas wilayah provinsi tetap menjadi kewenangan Pemerintah Pusat dalam hal ini Menteri.

Berdasarkan Peraturan Pemerintah No. 23 Tahun 2010 tentang Pelaksanaan Kegiatan Usaha Pertambangan Mineral dan Batubara, WIUP diberikan secara lelang. Sebelum dilakukan pelelangan WIUP batubara sebagaimana Gubernur atau Menteri sesuai dengan kewenangannya mengumumkan secara terbuka WIUP yang akan dilelang kepada badan usaha, koperasi, atau perseorangan dalam jangka waktu paling lambat 3 (tiga) bulan sebelum pelaksanaan lelang. Selanjutnya Gubernur atau Menteri akan membentuk panitia lelang. Panitia lelang yang dibentuk oleh Gubernur beranggotakan gasal dan paling sedikit terdiri dari 5 (lima) orang yang memiliki kompetensi di bidang pertambangan batubara. Sedangkan panitia lelang yang dibentuk oleh Menteri beranggotakan gasal dan paling sedikit 7 (tujuh) orang yang memiliki kompetensi di bidang pertambangan batubara. Dalam panitia lelang ini, Gubernur maupun Menteri dapat mengikutsertakan unsur dari Pemerintah lainnya.

Tugas dan wewenang panitia lelang WIUP batubara meliputi: Menyiapkan lelang WIUP; Menyiapkan dokumen lelang WIUP; Menyusun jadwal lelang WIUP; Mengumumkan waktu pelaksanaan lelang WIUP; Melaksanakan pengumuman ulang paling banyak 2 (dua) kali, apabila peserta lelang WIUP hanya 1 (satu); Menilai kualifikasi peserta lelang WIUP; Melakukan evaluasi terhadap penawaran yang masuk; Melaksanakan lelang WIUP; dan Membuat berita acara hasil pelaksanaan lelang dan mengusulkan pemenang lelang WIUP.

Untuk mengikuti lelang, peserta lelang WIUP harus memenuhi persyaratan administratif, persyaratan teknis, dan persyaratan finansial. Persyaratan administratif yang diperlukan untuk badan usaha meliputi: Mengisi formulir yang sudah disiapkan panitia lelang; Profil badan usaha; Akte pendirian badan usaha yang bergerak di bidang usaha pertambangan yang telah disahkan oleh pejabat yang berwenang; dan Nomor Pokok Wajib Pajak.

Persyaratan teknis paling sedikit meliputi: Pengalaman badan usaha, koperasi, atau perseorangan di bidang pertambangan mineral atau batubara paling sedikit 3 (tiga) tahun, atau bagi perusahaan baru harus mendapat dukungan dari perusahaan induk, mitra kerja, atau afiliasinya yang bergerak di bidang pertambangan; Mempunyai paling sedikit 1 (satu) orang tenaga ahli dalam bidang pertambangan dan/ atau geologi yang berpengalaman paling sedikit 3 (tiga) tahun; dan Rencana kerja dan anggaran biaya untuk kegiatan 4 (empat) tahun eksplorasi.

Persyaratan finansial meliputi: Laporan keuangan tahun terakhir yang sudah diaudit akuntan publik; Menempatkan jaminan kesungguhan lelang dalam bentuk uang tunai di Bank Pemerintah sebesar $10 \%$ (sepuluh persen) dari nilai kompensasi data informasi atau dari total biaya pengganti investasi untuk lelang WIUP yang telah berakhir; dan Pernyataan bersedia membayar nilai lelang WIUP dalam jangka waktu paling lambat 5 (lima) hari kerja, setelah pengumuman pemenang lelang.

Prosedur lelang memerlukan beberapa tahapan, antara lain: Pengumuman prakualifikasi; Pengambilan dokumen prakualifikasi; Pemasukan dokumen prakualifikasi; Evaluasi prakualifikasi; Klarifikasi dan konfirmasi terhadap dokumen prakualifikasi; Penetapan hasil prakualifikasi; Pengumuman hasil prakualifikasi; Undangan kepada peserta yang lulus prakualifikasi; Pengambilan dokumen lelang; Penjelasan lelang; Pemasukan penawaran harga; Pembukaan sampul; Penetapan peringkat; Penetapan/pengumuman pemenang lelang yang dilakukan berdasarkan penawaran harga dan pertimbangan teknis; dan Memberi kesempatan adanya sanggahan atas keputusan lelang. 
Selanjutnya, kepada peserta lelang yang telah lulus tahap prakualifikasi, panita lelang wajib memberikan penjelasan data teknis berupa: Lokasi; Koordinat; Jenis cadangan batubara; Ringkasan hasil penelitian dan penyelidikan; Ringkasan hasil eksplorasi pendahuluan apabila ada; dan Status lahan.

Panitia lelang sesuai dengan kewenangannya yang memberikan kesempatan kepada peserta pelelangan WIUP yang lulus prakualifikasi untuk melakukan kunjungan lapangan dalam jangka waktu yang disesuaikan dengan jarak lokasi yang akan dilelang. Dalam hal peserta pelelangan WIUP yang akan melakukan kunjungan lapangan mengikutsertakan warga negara asing wajib memenuhi persyaratan sesuai dengan ketentuan peraturan perundang-undangan. Biaya yang diperlukan untuk melakukan kunjungan lapangan dibebankan kepada peserta pelelangan WIUP. Jangka waktu prosedur pelelangan ditetapkan paling lama 35 (tiga puluh lima) hari kerja sejak pemasukan penawaran harga. Hasil pelaksanaan lelang WIUP dilaporkan oleh panitia lelang kepada Menteri atau Gubernur sesuai kewenangannya.

Menteri atau Gubernur dengan kewenangannya berdasarkan usulan panitia lelang menetapkan pemenang lelang WIUP batubara. Menteri atau Gubernur sesuai dengan kewenangannya memberitahukan secara tertulis penetapan pemenang lelang WIUP batubara kepada pemenang lelang. Apabila peserta lelang yang memasukan penawaran harga hanya terdapat 1 (satu) peserta lelang, maka akan dilakukan pelelangan ulang. Dalam hal peserta lelang ulang tetap hanya diikuti oleh 1 (satu) peserta, maka peserta tersebut akan ditetapkan sebagai pemenang lelang dengan ketentuan harga penawaran harus sama atau lebih tinggi dari harga dasar lelang yang telah ditetapkan. IUP Eksplorasi untuk pertambangan batubara dapat diberikan dalam jangka waktu paling lama 7 (tujuh) tahun. Setiap pemegang IUP Eksplorasi dijamin untuk memperoleh IUP Operasi Produksi sebagai kelanjutan kegiatan usaha pertambangannya. Pemegang IUP Eksplorasi Batubara diberi WIUP dengan luas paling sedikit 5.000 (lima ribu) hektare dan paling banyak 50.000 (lima puluh ribu) hektare.

Kedua, IUP Operasi Produksi adalah izin usaha yang diberikan setelah selesai pelaksanaan IUP Eksplorasi untuk melakukan tahapan kegiatan operasi produksi. IUP Operasi Produksi dapat diberikan kepada badan usaha, koperasi, atau perseorangan atas hasil pelelangan WIUP batubara yang telah mempunyai data hasil kajian studi kelayakan.

IUP Operasi Produksi diberikan oleh: Bupati/ Walikota apabila lokasi penambangan, lokasi pengolahan dan pemurnian, serta pelabuhan berada di dalam satu wilayah kabupaten/kota; Gubernur apabila lokasi penambangan, lokasi pengolahan dan pemurnian, serta pelabuhan berada di dalam wilayah kabupaten/ kota yang berbeda setelah mendapatkan rekomendasi dari Bupati/Walikota setempat sesuai dengan ketentuan peraturan perundang-undangan; dan Menteri apabila lokasi penambangan, lokasi pengolahan dan pemurnian, serta pelabuhan berada di dalam wilayah provinsi yang berbeda setelah mendapatkan rekomendasi dari Gubernur dan Bupati/ Walikota setempat sesuai dengan ketentuan peraturan perundang-undangan.

Akan tetapi Berdasarkan Undang-Undang No. 23 Tahun 2014 tentang Pemerintah Daerah dan Peraturan Pemerintah Pengganti Undang-Undang (Perppu) No. 2 Tahun 2014, Bupati/Walikota tidak lagi mempunyai kewenangan untuk menebitkan Izin Usaha Pertambangan (IUP) di daerahnya. Kewenangan untuk menerbitkan IUP kini menjadi milik pemerintah provinsi, dalam hal ini Gubernur. Apabila WIUP berada pada lintas wilayah provinsi tetap menjadi kewenangan Pemerintah Pusat dalam hal ini Menteri.

Berdasarkan Peraturan Pemerintah No. 23 Tahun 2010 tentang Pelaksanaan Kegiatan Usaha Pertambangan Mineral dan Batubara, WIUP diberikan secara lelang. Sebelum dilakukan pelelangan WIUP batubara sebagaimana Gubernur atau Menteri sesuai dengan kewenangannya mengumumkan secara terbuka WIUP yang akan dilelang kepada badan usaha, koperasi, atau perseorangan dalam jangka waktu paling lambat 3 (tiga) bulan sebelum pelaksanaan lelang. Selanjutnya Gubernur atau Menteri akan membentuk panitia lelang. Panitia lelang yang dibentuk oleh Gubernur beranggotakan gasal dan paling sedikit terdiri dari 5 (lima) orang yang memiliki kompetensi di bidang pertambangan batubara. Sedangkan panitia lelang yang dibentuk oleh Menteri beranggotakan gasal dan paling sedikit 7 (tujuh) orang yang memiliki kompetensi di bidang pertambangan batubara. Dalam panitia lelang ini, 
Gubernur maupun Menteri dapat mengikutsertakan unsur dari Pemerintah lainnya.

Tugas dan wewenang panitia lelang WIUP batubara meliputi: Menyiapkan lelang WIUP; Menyiapkan dokumen lelang WIUP; Menyusun jadwal lelang WIUP; Mengumumkan waktu pelaksanaan lelang WIUP; Melaksanakan pengumuman ulang paling banyak 2 (dua) kali, apabila peserta lelang WIUP hanya 1 (satu); Menilai kualifikasi peserta lelang WIUP; Melakukan evaluasi terhadap penawaran yang masuk; Melaksanakan lelang WIUP; dan Membuat berita acara hasil pelaksanaan lelang dan mengusulkan pemenang lelang WIUP.

Untuk mengikuti lelang, peserta lelang WIUP harus memenuhi persyaratan administratif, persyaratan teknis, dan persyaratan finansial. Persyaratan administratif yang diperlukan untuk badan usaha meliputi: Mengisi formulir yang sudah disiapkan panitia lelang; Profil badan usaha; Akte pendirian badan usaha yang bergerak di bidang usaha pertambangan yang telah disahkan oleh pejabat yang berwenang; dan Nomor pokok wajib pajak.

Persyaratan teknis paling sedikit meliputi: Pengalaman badan usaha, koperasi, atau perseorangan di bidang pertambangan mineral atau batubara paling sedikit 3 (tiga) tahun, atau bagi perusahaan baru harus mendapat dukungan dari perusahaan induk, mitra kerja, atau afiliasinya yang bergerak di bidang pertambangan; Mempunyai paling sedikit 1 (satu) orang tenaga ahli dalam bidang pertambangan dan/ atau geologi yang berpengalaman paling sedikit 3 (tiga) tahun; dan Rencana kerja dan anggaran biaya untuk kegiatan 4 (empat) tahun eksplorasi.

Persyaratan finansial meliputi: Laporan keuangan tahun terakhir yang sudah diaudit akuntan publik; Menempatkan jaminan kesungguhan lelang dalam bentuk uang tunai di bank pemerintah sebesar $10 \%$ (sepuluh persen) dari nilai kompensasi data informasi atau dari total biaya pengganti investasi untuk lelang WIUP yang telah berakhir; dan Pernyataan bersedia membayar nilai lelang WIUP dalam jangka waktu paling lambat 5 (lima) hari kerja, setelah pengumuman pemenang lelang.

Prosedur lelang memerlukan beberapa tahapan, antara lain: Pengumuman prakualifikasi; Pengambilan dokumen prakualifikasi; Pemasukan dokumen prakualifikasi; Evaluasi prakualifikasi;
Klarifikasi dan konfirmasi terhadap dokumen prakualifikasi; Penetapan hasil prakualifikasi; Pengumuman hasil prakualifikasi; Undangan kepada peserta yang lulus prakualifikasi; Pengambilan dokumen lelang; Penjelasan lelang; Pemasukan penawaran harga; Pembukaan sampul; Penetapan peringkat; Penetapan/pengumuman pemenang lelang yang dilakukan berdasarkan penawaran harga dan pertimbangan teknis; dan Memberi kesempatan adanya sanggahan atas keputusan lelang.

Selanjutnya, kepada peserta lelang yang telah lulus tahap prakualifikasi, panita lelang wajib memberikan penjelasan data teknis berupa: Lokasi; Koordinat; Jenis cadangan batubara; Ringkasan hasil penelitian dan penyelidikan; Ringkasan hasil eksplorasi pendahuluan apabila ada; dan Status lahan.

Panitia lelang sesuai dengan kewenangannya yang memberikan kesempatan kepada peserta pelelangan WIUP yang lulus prakualifikasi untuk melakukan kunjungan lapangan dalam jangka waktu yang disesuaikan dengan jarak lokasi yang akan dilelang. Dalam hal peserta pelelangan WIUP yang akan melakukan kunjungan lapangan mengikutsertakan warga negara asing wajib memenuhi persyaratan sesuai dengan ketentuan peraturan perundangundangan. Biaya yang diperlukan untuk melakukan kunjungan lapangan dibebankan kepada peserta pelelangan WIUP. Jangka waktu prosedur pelelangan ditetapkan dalam jangka waktu paling lama 35 (tiga puluh lima) hari kerja sejak pemasukan penawaran harga. Hasil pelaksanaan lelang WIUP dilaporkan oleh panitia lelang kepada Menteri atau Gubernur sesuai kewenangannya.

Menteri atau Gubernur dengan kewenangannya berdasarkan usulan panitia lelang menetapkan pemenang lelang WIUP batubara. Menteri atau Gubernur sesuai dengan kewenangannya memberitahukan secara tertulis penetapan pemenang lelang WIUP batubara kepada pemenang lelang. Apabila peserta lelang yang memasukan penawaran harga hanya terdapat 1 (satu) peserta lelang, maka akan dilakukan pelelangan ulang. Dalam hal peserta lelang ulang tetap hanya diikuti oleh 1 (satu) peserta, maka peserta tersebut akan ditetapkan sebagai pemenang lelang dengan ketentuan harga penawaran harus sama atau lebih tinggi dari harga dasar lelang yang telah ditetapkan. 
IUP Operasi Produksi untuk Pertambangan batubara dapat diberikan dalam jangka waktu paling lama 20 (dua puluh) tahun dan dapat diperpanjang 2 (dua) kali masing-masing 10 (sepuluh) tahun. Pemegang IUP Operasi Produksi batubara diberi WIUP dengan luas paling banyak 15.000 (lima belas ribu) hektare. Sejak diterbitkannya Peraturan Pemerintah No. 23 Tahun 2010 tentang Pelaksanaan Kegiatan Usaha Pertambangan Mineral dan Batubara, hingga saat ini belum ada WIUP hasil lelang yang diterbitkan baik oleh Menteri maupun oleh Gubernur. Hal ini dikarenakan petunjuk teknis mengenai lelang WIUP yaitu berupa Keputusan Menteri ESDM belum diterbitkan.

Seluruh IUP yang ada saat ini adalah hasil dari penyesuaian Kuasa Pertambangan. Sebelum terbitnya Undang-undang No. 4 Tahun 2009 tentang Pertambangan Mineral dan Batubara, IUP disebut dengan Kuasa Pertambangan hal ini berdasarkan Undang-Undang No. 11 Tahun 1967 tentang Ketentuan-Ketentuan Pokok Pertambangan. Sebelum tahun 2009, banyak Kuasa Pertambangan yang diterbitkan oleh pemerintah, baik Pemerintah Kabupaten maupun Pemerintah Provinsi. Kuasa Pertambangan adalah wewenang yang diberikan kepada badan/perseorangan untuk melaksanakan usaha pertambangan. Kuasa Pertambangan dibagi menjadi 3, yaitu Kuasa Pertambangan Penyelidikan Umum, Kuasa Pertambangan Eksplorasi dan Kuasa Pertambangan Eksploitasi.

Pertama, Kuasa Pertambangan Penyelidikan umum adalah wewenang yang diberikan oleh pemerintah kepada badan/perseorangan untuk melakukan penyelidikan secara geologi umum atau geofisika, didaratan, perairan dan dari udara, segala sesuatu dengan maksud untuk membuat peta geologi umum atau untuk menetapkan tanda-tanda adanya bahan galian pada umumnya. Kuasa Pertambangan yang berisikan wewenang untuk melakukan usaha pertambangan penyelidikan umum disebut Kuasa Pertambangan Penyelidikan Umum. Kuasa Pertambangan Penyelidikan Umum diberikan oleh Menteri untuk jangka waktu selama 1 (satu) tahun, atas permintaan yang bersangkutan. Menteri dapat memperpanjang jangka waktu Kuasa Pertambangan Penyelidikan umum untuk jangka waktu 1 (satu) tahun lagi, atas permintaan yang bersangkutan yang diajukan sebelum berakhirnya jangka waktu yang telah ditetapkan.

Dalam permintaan Kuasa Pertambangan Penyelidikan Umum harus dilampirkan peta wilayah Kuasa Pertambangan yang diminta dengan penunjukan batas-batas yang jelas. Peta ini merupakan peta bagan dengan skala sekecilkecilnya 1: 200.000 (satu berbanding dua ratus ribu). Pemegang Kuasa Pertambangan Penyelidikan Umum yang menemukan suatu bahan galian dalam wilayah Kuasa Pertambangannya, mendapat prioritas pertama untuk memperoleh Kuasa Pertambangan Eksplorasi atas bahan galian tersebut.

Suatu wilayah Kuasa Pertambangan Penyelidikan Umum diberikan dalam proyeksi tegak lurus dari sebidang tanah yang luasnya ditentukan pada pemberian Kuasa Pertambangan yang bersangkutan. Luas wilajah yang dapat diberikan untuk satu Kuasa Pertambangan Penyelidikan Umum tidak boleh melebihi 5.000 (lima ribu) hektare. Untuk mendapat satu Kuasa Pertambangan Penyelidikan Umum yang luas wilajahnya melebihi 5.000 (lima ribu) Ha, maka peminta Kuasa Pertambangan Penyelidikan Umum harus terlebih dahulu mendapat izin khusus dari Menteri, sehingga luas total Kuasa Pertambangan Penyelidikan Umum yang dapat diberikan adalah seluas 25.000 (dua puluh lima ribu) Ha dari wilajah hukum pertambangan Indonesia.

Kedua, Kuasa Pertambangan Eksplorasi adalah wewenang yang diberikan oleh pemerintah kepada badan atau perseorangan untuk melakukan segala penyelidikan geologi pertambangan untuk menetapkan lebih teliti atau seksama adanya dan sifat letakan bahan galian. Kuasa Pertambangan yang berisikan wewenang untuk melakukan usaha pertambangan eksplorasi disebut Kuasa Pertambangan Eksplorasi. Kuasa Pertambangan Eksplorasi diberikan oleh Menteri untuk jangka waktu selama-lamanya 3 (tiga) tahun, atas permintaan yang bersangkutan. Menteri dapat memperpanjang jangka waktu Kuasa Pertambangan Eksplorasi sebanyak 2 (dua) kali, setiap kalinya untuk jangka waktu 1 (satu) tahun atas permintaan yang bersangkutan, yang harus diajukan sebelum berakhirnya jangka waktu yang telah ditetapkan. Dalam hal pemegang Kuasa Pertambangan Eksplorasi telah menyatakan bahwa usahanya akan dilanjutkan dengan usaha pertambangan eksploitasi, maka Menteri dapat 
memberikan perpanjangan jangka waktu Kuasa Pertambangan Eksplorasi selama 3 (tiga) tahun lagi untuk pembangunan fasilitas-fasilitas eksploitasi pertambangan, atas permintaan yang bersangkutan.

Dalam permintaan Kuasa Pertambangan Penyelidikan Umum harus dilampirkan peta wilajah Kuasa Pertambangan yang diminta dengan penunjukan batas-batas yang jelas. Peta ini merupakan peta bagan dengan skala sekecilkecilnya 1:50.000 (satu berbanding lima puluh ribu). Pemegang Kuasa Pertambangan Eksplorasi yang telah membuktikan hasil baik eksplorasinya atas bahan galian yang disebutkan dalam Kuasa Pertambangannya, mendapat hak tunggal untuk memperoleh Kuasa Pertambangan Eksplorasi atas bahan galian tersebut.

Suatu wilayah Kuasa Pertambangan Eksplorasi, diberikan dalam proyeksi tegak lurus dari sebidang tanah yang luasnya ditentukan pada pemberian Kuasa Pertambangan yang bersangkutan. Luas wilayah yang dapat diberikan untuk satu Kuasa Pertambangan Eksplorasi tidak boleh melebihi 2.000 (dua ribu) hektare. Untuk mendapat satu Kuasa Pertambangan Eksplorasi yang luas wilajahnya melebihi 2.000 (dua ribu) hektare, maka peminta Kuasa Pertambangan Eksplorasi harus terlebih dahulu mendapat izin khusus dari Menteri, sehingga luas total Kuasa Pertambangan Eksplorasi yang dapat diberikan adalah seluas 10.000 (sepuluh ribu) Ha dari wilayah hukum pertambangan Indonesia.

Ketiga, Kuasa Pertambangan eksploitasi adalah wewenang yang diberikan oleh pemerintah kepada badan atau perseorangan untuk kegiatan usaha pertambangan dengan maksud untuk menghasilkan bahan galian dan memanfaatkannya. Kuasa Pertambangan yang berisikan wewenang untuk melakukan usaha pertambangan eksploitasi disebut kuasa Pertambangan Eksploitasi. Kuasa Pertambangan Eksploitasi diberikan oleh Menteri untuk jangka watu selama-lamanya 30 (tiga puluh) tahun, atas permintaan yang bersangkutan. Menteri dapat memperpanjang jangka Kuasa Pertambangan Eksploitasi sebanyak 2 (dua) kali, setiap kalinya untuk jangka waktu 10 (sepuluh) tahun atas permintaan yang bersangkutan yang harus diajukan sebelum berakhirnya jangka waktu yang telah ditetapkan.

Dalam permintaan Kuasa Pertambangan Penyelidikan Umum harus dilampirkan peta wilayah Kuasa Pertambangan yang diminta dengan penunjukan batas-batas yang jelas. Peta ini merupakan peta bagan dengan skala sekecil-kecilnya 1:10.000 (satu berbanding sepuluh ribu). Peta Kuasa Pertambangan Eksploitasi ini harus menjelaskan dan menunjukkan: pertama, Ukuran arah astronomis dan jarak dari titik ketitik batas wilayah Kuasa Pertambangan yang tidak boleh melebihi 500 (lima ratus) meter; kedua, Bahwa salah satu titik batas harus dihubungkan dengan salah satu titik triangulasi atau titik induk tetap lainya yang tergambar dalam peta dasar yang dikeluarkan oleh intansi yang berwenang dalam bidang topografi; ketiga, Tempat terdapatnya bahan galian diukur dari salah satu titik batas wilajah Kuasa Pertambangan; keempat, Gambar letak wilayah Pertambangan Rakyat jika ada.

Suatu wilayah Kuasa Pertambangan Eksploitasi, diberikan dalam proyeksi tegak lurus dari sebidang tanah yang luasnya ditentukan pada pemberian Kuasa Pertambangan yang bersangkutan. Luas wilajah yang dapat diberikan untuk satu Kuasa Pertambangan Eksploitasi tidak boleh melebihi 1.000 (seribu) hektare. Untuk mendapat satu Kuasa Pertambangan Eksploitasi yang luas wilayahnya melebihi 1.000 (seribu) hektare, maka peminta Kuasa Pertambangan Eksploitasi harus terlebih dahulu mendapat izin khusus dari Menteri, sehingga luas total Kuasa Pertambangan Eksploitasi yang dapat diberikan adalah seluas 5.000 (lima ribu) Ha dari wilajah hukum pertambangan Indonesia.

Pembentukan perusahaan baru yang dilanjutkan dengan permohonan dan/atau pemberian Izin Kuasa Pertambangan pada periode ini secara ringkas akan penulis jelaskan sebagai berikut: PT. A mengajukan permohonan untuk mendapatkan Kuasa Pertambangan Penyelidikan Umum pada area dengan luas maksimal 25.000 (dua puluh lima ribu) Ha untuk melakukan kegiatan penyelidikan, pencarian, atau penemuan endapan-endapan batubara. Dengan kata lain kegiatan ini bertujuan untuk menemukan keberadaan atau indikasi adanya bahan galian batubara yang akan dapat atau memberikan harapan untuk diselidiki lebih lanjut. Jika pada tahap prospeksi ini tidak ditemukan adanya cadangan bahan galian batubara yang berprospek untuk diteruskan sampai ke tahapan eksplorasi, maka kegiatan ini harus dihentikan. Apabila tetap diteruskan akan menghabiskan dana secara sia-sia. 
Sering juga tahapan prospeksi ini dilewatkan karena dianggap sudah ditemukan adanya indikasi atau tanda-tanda keberadaan bahan galian yang sudah langsung bisa dieksplorasi.

Setelah ditemukannya adanya cadangan bahan galian batubara yang berprospek, maka PT. A mengajukan permohonan untuk mendapatkan Kuasa Pertambangan Eksplorasi pada sebagian areal Kuasa Pertambangan Penyelidikan Umum dengan luas areal maksimal 10.000 (sepuluh ribu) Ha. Adapun areal yang dianggap tidak memiliki potensi atau kandungan batubaranya tidak dimohon atau tidak ditingkatkan statusnya menjadi Kuasa Pertambangan Eksplorasi, sebagaimana Gambar 2.

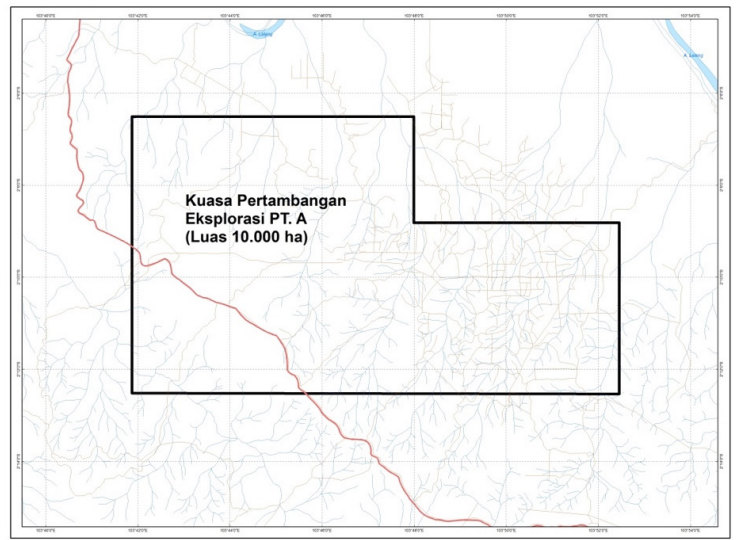

Gambar 2. Peta Permohonan Kuasa Pertambangan Ekplorasi PT. A Seluas $10.000 \mathrm{Ha}$

Setelah mendapatkan Kuasa Pertambangan Eksplorasi tahap selanjutnya adalah PT. A melakukan kegiatan eksplorasi batubara terhadap areal seluas 10.000 (sepuluh ribu) Ha tersebut. Adapun tahapan kegiatan eksplorasi batubara dimaksud adalah sebagai berikut:

Pertama, Survei Tinjau (Reconnaissance). Survei tinjau merupakan tahap eksplorasi batubara yang paling awal dengan tujuan mengidentifikasi daerah-daerah yang secara geologis mengandung endapan batubara yang berpotensi untuk diselidiki lebih lanjut serta mengumpulkan informasi tentang kondisi geografi, tata guna lahan, dan kesampaian daerah. Kegiatannya, antara lain, studi geologi regional, penafsiran penginderaan jauh, metode tidak langsung lainnya, serta inspeksi lapangan pendahuluan yang menggunakan peta dasar dengan skala sekurang-kurangnya 1:100.000.

Kedua, Prospeksi (Prospecting). Tahap eksplorasi ini dimaksudkan untuk membatasi daerah sebaran endapan yang akan menjadi sasaran eksplorasi selanjutnya. Kegiatan yang dilakukan pada tahap ini di antaranya, pemetaan geologi dengan skala minimal 1:50.000, pengukuran penampang stratigrafi, pembuatan paritan, pembuatan sumuran, pemboran uji (scout drilling), pencontohan dan analisis. Metode tidak langsung, seperti penyelidikan geofisika, dapat dilaksanakan apabila dianggap perlu. Logging geofisik berkembang dalam ekplorasi minyak bumi untuk analisa kondisi geologi dan reservior minyak. Logging geofisik untuk eksplorasi batubara dirancang tidak hanya untuk mendapatkan informasi geologi, tetapi untuk memperoleh berbagai data lain, seperti kedalaman, ketebalan dan kualitas lapisan batubara, dan sifat geomekanik batuan yang menyertai penambahan batubara dan juga mengkompensasi berbagai masalah yang tidak terhindar apabila hanya dilakukan pengeboran, yaitu pengecekan kedalaman sesungguhnya dari lapisan penting, terutama lapisan batubara atau sequence rinci dari lapisan batubara termasuk parting dan lain lain.

Ketiga, Eksplorasi Pendahuluan (Preliminary Exploration). Tahap eksplorasi ini dimaksudkan untuk mengetahui kuantitas dan kualitas serta gambaran awal bentuk tiga dimensi endapan batubara. Kegiatan yang dilakukan antara lain, pemetaan geologi dengan skala minimal 1:10.000, pemetaan topografi, pemboran dengan jarak yang sesuai dengan kondisi geologinya, penampangan (logging) geofisika, pembuatan sumuran/paritan uji, dan pencontohan yang andal. Pengkajian awal geoteknik dan geohidrologi mulai dapat dilakukan.

Keempat, Eksplorasi Rinci (Detailed Exploration). Tahap eksplorasi ini dimaksudkan untuk mengetahui kuantitas dan kualitas serta bentuk tiga dimensi endapan batubara. Kegiatan yang harus dilakukan adalah pemetaan geologi dan topografi dengan skala minimal 1:2.000, pemboran, dan pencontohan yang dilakukan dengan jarak yang sesuai dengan kondisi geologinya, penampangan (logging) geofisika, pengkajian geohidrologi, dan geoteknik. Pada tahap ini perlu dilakukan pencontohan batuan, batubara dan lainnya yang dipandang perlu sebagai bahan pengkajian lingkungan yang berkaitan dengan rencana kegiatan penambangan.

Kelima, Penyusunan Dokumen Laporan Akhir Eksplorasi. Setiap kegiatan eksplorasi harus didokumentasikan dalam bentuk laporan tertulis yang 
berisi seluruh kegiatan yang telah dilakukan dan hasil yang diperoleh, terutama informasi mengenai keterdapatan, sebaran, kuantitas dan kualitas batubara. Laporan tersebut sangat penting artinya bukan hanya bagi usaha pertambangan karena akan dapat digunakan sebagai acuan untuk menentukan kegiatan berikutnya, tetapi juga bagi Pemerintah/ Pemerintah Daerah dalam rangka inventarisasi sumberdaya batubara. Sistematika penyusunan Laporan Akhir Eksplorasi ini mengacu pada Lampiran XIII a (Pedoman Penyusunan Laporan Penyelidikan Umum dan Eksplorasi), Keputusan Menteri ESDM No. 1453 K/29/MEM/2000 tentang Pedoman Teknis Penyelenggaraan Tugas Pemerintahan di Bidang Pertambangan Umum Menteri Energi dan Sumber Daya Mineral.

Keenam, Penyusunan Dokumen Studi Kelayakan. Studi kelayakan merupakan tahapan akhir dari rentetan penyelidikan awal yang dilakukan sebelumnya sebagai penentu apakah kegiatan penambangan endapan bahan galian batubara tersebut layak dilakukan atau tidak. Dasar pertimbangan yang digunakan meliputi pertimbangan teknis dan ekonomis dengan teknologi yang ada pada saat ini, dan dengan memperhatikan keselamatan kerja serta kelestarian lingkungan hidup. Bila tidak atau belum layak maka data tersebut diarsipkan. Sistematika penyusunan dokumen Studi Kelayakan ini mengacu pada Lampiran XIII b (Pedoman Penyusunan Laporan Studi Kelayakan, Eksploitasi dan Produksi), Keputusan Menteri ESDM No. $1453 \mathrm{~K} / 29 / \mathrm{MEM} / 2000$ tentang Pedoman Teknis Penyelenggaraan Tugas Pemerintahan Di Bidang Pertambangan Umum Menteri Energi Dan Sumber Daya Mineral.

Ketujuh, Penyusunan Dokumen Lingkungan Hidup (AMDAL). Bagi badan, perusahaan dan/atau perorangan yang memiliki Izin Usaha Pertambangan Operasi Produksi wajib memiliki Dokumen Lingkungan Hidup, hal ini berdasarkan Peraturan Menteri Negara Lingkungan Hidup Republik Indonesia No. 05 Tahun 2012 Tentang Jenis Rencana Usaha dan/atau Kegiatan Yang Wajib Memiliki Analisis Mengenai Dampak Lingkungan Hidup. Sistematika penyusunan Dokumen Lingkungan Hidup ini mengacu pada Peraturan Menteri Negara Lingkungan Hidup Republik Indonesia No. 16 Tahun 2012 tentang Pedoman Penyusunan Dokumen
Lingkungan Hidup. Adapun klasifikasi dokumen lingkungan hidup adalah sebagai berikut: pertama, Analisis Mengenai Dampak Lingkungan Hidup (AMDAL), adalah kajian mengenai dampak penting suatu Usaha dan/atau Kegiatan yang direncanakan pada lingkungan hidup yang diperlukan bagi proses pengambilan keputusan tentang penyelenggaraan Usaha dan/atau Kegiatan. Badan, perusahaan dan/ atau perorangan wajib AMDAL apabila: a) Luas wilayah kegiatan operasi produksi berkorelasi dengan luas penyebaran dampak $\geq 200 \mathrm{ha}$ ); b) Kapasitas produksi batubara $\geq 1.000 .000$ ton/tahun dan Jumlah material penutup yang dipindahkan $\geq$ 4.000.000 bank cubic meter (bcm)/tahun; kedua, Dokumen Upaya Pengelolaan Lingkungan Hidup dan Upaya Pemantauan Lingkungan Hidup (UKLUPL), adalah pengelolaan dan pemantauan terhadap Usaha dan/atau Kegiatan yang tidak berdampak penting terhadap lingkungan hidup yang diperlukan bagi proses pengambilan keputusan tentang Badan, perusahaan dan/atau perorangan wajib UKL-UPL apabila: a) Luas wilayah kegiatan operasi produksi berkorelasi dengan luas penyebaran dampak $\leq 200$ ha); b) Kapasitas produksi batubara $\leq 1.000 .000$ ton/ tahun dan Jumlah material penutup yang dipindahkan $\leq 4.000 .000$ bank cubic meter (bcm)/ tahun.

Kedelapan, Penyusunan Dokumen Rencana Reklamasi dan Dokumen Rencana Pascatambang. Reklamasi adalah kegiatan yang dilakukan sepanjang tahapan usaha pertambangan untuk menata, memulihkan, dan memperbaiki kualitas lingkungan dan ekosistem agar dapat berfungsi kembali sesuai peruntukannya. Sementara itu, Kegiatan Pascatambang adalah kegiatan terencana, sistematis, dan berlanjut setelah akhir sebagian atau seluruh kegiatan usaha pertambangan untuk memulihkan fungsi lingkungan alam dan fungsi sosial menurut kondisi lokal di seluruh wilayah pertambangan. Berdasarkan Peraturan Menteri Energi Dan Sumber Daya Mineral Republik Indonesia No. 07 Tahun 2014 tentang Pelaksanaan Reklamasi dan Pascatambang Pada Kegiatan Usaha Pertambangan Mineral dan Batubara, pemegang IUP Eksplorasi sebelum melakukan kegiatan Eksplorasi wajib menyusun rencana Reklamasi tahap Eksplorasi berdasarkan Dokumen Lingkungan Hidup yang telah disetujui oleh instansi yang berwenang sesuai dengan ketentuan peraturan perundang-undangan di bidang 
perlindungan dan pengelolaan lingkungan hidup. Pemegang IUP Eksplorasi dan IUPK Eksplorasi yang telah menyelesaikan kegiatan Studi Kelayakan wajib menyusun rencana Reklamasi Tahap Operasi Produksi dan rencana Pascatambang berdasarkan Dokumen Lingkungan Hidup yang telah disetujui oleh instansi yang berwenang sesuai dengan ketentuan peraturan perundang-undangan di bidang perlindungan dan pengelolaan lingkungan hidup.

Tahap selanjutnya adalah PT. A mengajukan permohonan peningkatan status Kuasa Pertambangan dari Eksplorasi menjadi Kuasa Pertambangan Eksploitasi. Areal yang dimohon ini adalah sebagian areal prospek yang memiliki kandungan batubara yang didapat dari kajian tahapan ekplorasi sebelumnya. Adapun areal yang dimohon Kuasa Pertambangan Eksploitasi tidak boleh melebihi luas maksimal yaitu 5.000 (lima ribu) Ha. PT. A menganggap areal yang memiliki potensi cadangan batubara adalah seluas 2.500 (dua ribu lima ratus) Ha. Oleh karena itu, PT. A mengajukan permohonan Kuasa Pertambangan Eksploitasi untuk areal seluas 2.500 (dua ribu lima ratus) Ha.

Setelah mendapatkan Kuasa Pertambangan

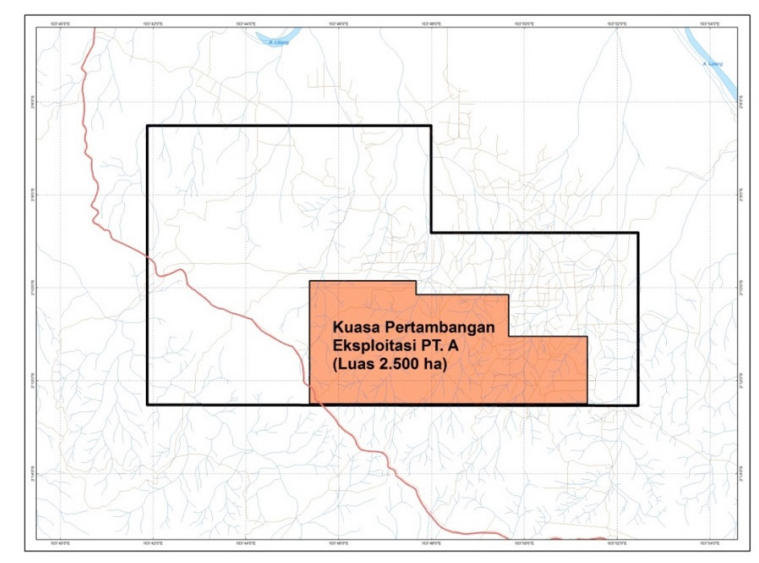

Gambar 3. Peta Permohonan Kuasa Pertambangan Ekplorasi PT. A Seluas $2.500 \mathrm{Ha}$

Eksploitasi seluas seluas 2.500 (dua ribu lima ratus) Ha, tahap selanjutnya adalah PT. A melakukan kegiatan eksploitasi batubara terhadap areal tersebut, sebagaimana dalam Gambar 3. Adapun tahapan kegiatan eksploitasi batubara dimaksud terdiri dari tahap pra-konstruksi, tahap konstruksi, tahap operasi, dan tahap pasca operasi. Adapun penjelasan tahapan tersebut adalah sebagai berikut:

Pada Tahapan Pra-Konstruksi ini terdapat beberapa kegiatan, antara lain: Pertama,
Kegiatan Sosialisasi, Komunikasi dan Koordinasi Multistakeholder. Pada dasarnya dimaksudkan untuk menyampaikan informasi tentang rencana kegiatan (proyek) tambang batubara di lokasi Kuasa Pertambangan Eksploitasi PT. A kepada warga masyarakat desa di sekitar lokasi tambang guna memperoleh masukan, tanggapan, saran dan pertimbangan masyarakat dan stakeholder terkait atas rencana proyek tambang batubara tersebut, sekaligus menyerap harapan dan aspirasi warga desa berkenaan rencana dan langkah-langkah perusahaan (investor) dalam penanga nan/penyelesaian masalah potensi lahan yang tumpang-tindih (overlap), pembebasan lahan masyarakat yang terkena lokasi kerja blok tambang, pengendalian pencemaran udara, tanah, air, estetika lingkungan, penanganan atau penyelesaian masalah kompensasi atau ganti-rugi tanah dan tumbuhan yang terkena proyek tambang batubara PT. A.

Kedua, Pembebasan Lahan Masyarakat. Kegiatan pembebasan lahan masyarakat yang terkena proyek tambang batubara di loksi Kuasa Pertambangan Eksploitasi PT. A merupakan sebuah keniscayaan terkait dengan status dan pola penguasaan atau pemilikan masyarakat atas sumberdaya lahan di dalam lokasi Kuasa Pertambangan Eksploitasi PT. A. Urgensi pembebasan lahan masyarakat merupakan hal yang tidak dapat dihindari mengingat pada sebagian areal yang akan diusahakan atau ditambang berada dalam klaim penguasaan atau pemilikan masyarakat yang ditunjukkan oleh keberadaan kebun kelapa sawit, perkebunan karet, areal perladangan dan pemukiman penduduk desa. Pembebasan lahan dilakukan dengan mengembangkan pendekatan dialog secara persuasif dan konstruktif dengan semangat musyawarah-mufakat dengan kepala desa, tokoh masyarakat serta pemilik hak atas tanah dan tanaman tumbuhan atau bangunan yang berada di atasnya.

Pada Tahapan Konstruksi ini terdapat beberapa kegiatan, antara lain: Pertama, Penerimaan Tenaga Kerja. Untuk mendukung berlangsungnya kegiatan konstruksi tambang, maka diperlukan tenaga kerja dalam jumlah yang cukup banyak serta memiliki kualifikasi (keterampilan) kerja yang sesuai dengan bidang pekerjaan. Terkait dengan penerimaan tenaga kerja pada tahap konstruksi ini, harus diprioritaskan menyerap tenaga kerja lokal minimal sebanyak $60 \%$ 
dari total kebutuhan tenaga kerjanya dari sumberdaya tenaga kerja lokal yang tersedia di desa-desa sekitar lingkar tambang.

Kedua, Mobilisasi Kendaraan, Peralatan Berat dan Material. Kegiatan ini dimaksudkan untuk mendukung pembangunan infrastruktur tambang dan utilitas, seperti jaringan jalan tambang, sarana kantor tambang (basecamp atau site), bengkel (unit kerja repair dan maintenance), gudang, mess, ruang genset, sarana pengolahan air bersih, dan sebagainya. Selain itu, mobilisasi kendaraan dan peralatan berat juga diperlukan dalam rangka kegiatan pembukaan dan pematangan lahan tambang.

Ketiga, Pembangunan Jalan dan Sarana dan Prasarana Tambang. Pembangunan jaringan jalan tambang dalam operasional penambangan batubara di areal Kuasa Pertambangan PT. A mencakup jalan tambang di dalam wilayah kerja blok tambang (pit) PT. A. Sementara pembangunan sarana prasarana penunjang operasional tambang batubara dalam ini mencakup bangunan kantor site dan mess, disposal area, settling pond serta beberapa sarana prasarana lainnya.

Keempat, Pembukaan dan Pematangan Lahan Tambang. Kegiatan pembukaan dan pematangan lahan tambang pada tahap konstruksi ditujukan untuk mempersiapkan jalan akses dan pembangunan sarana dan prasarana (infrastruktur) penunjang operasi tambang batubara. Kondisi awal (rona) lahan yang akan dibersihkan masih ditumbuhi vegetasi berupa semak, belukar dan vegetasi kebun karet campuran. Aktivitas yang menonjol pada kegiatan pembukaan dan pematangan lahan tambang adalah penebasan, penebangan dan pemotongan pohon, batang, cabang dan ranting untuk selanjutnya dilakukan pembersihan lahan dengan bantuan peralatan berat. Aktivitas landclearing untuk tapak jalan dan sarana prasarana tambang akan dilakukan secara cermat, memperhatikan aspek keamanan, keselamatan dan kelestarian lingkungan.

Pada Tahapan Operasi ini terdapat beberapa kegiatan, antara lain: Pertama, Penerimaan Tenaga Kerja. Penerimaaan tenaga kerja pada tahapan ini terbagi menjadi 2 (dua), yaitu tenaga kerja tetap dan tenaga kerja tidak tetap. Tenaga kerja tetap adalah tenaga kerja yang diangkat sebagai karyawan tetap perusahaan berdasarkan perjanjian kerja yang disepakati bersama. Yang termasuk dalam kelompok tenaga kerja tetap adalah para karyawan yang diangkat untuk mengisi formasi yang ada dalam struktur organisasi, meliputi level direksi, level manager, level kepala divisi dan level kepala bagian. Sementara itu, tenaga kerja tidak tetap adalah tenaga kerja yang diangkat sebagai karyawan tidak tetap oleh perusahaan berdasarkan perjanjian kerja yang disepakati bersama. Yang temasuk dalam kelompok tenaga kerja tidak tetap adalah karyawan yang direkruit secara kontrak untuk jangka waktu tertentu untuk melaksanakan pekerjaan operasi penambangan, preparasi batubara, dan pengangkutan.

Kedua, Pengupasan Lapisan Tanah Penutup. Kegiatan pengupasan lapisan tanah penutup akan dimulai dengan kegiatan pembersihan lahan dari vegetasi dan semak belukar yang ada. Lapisan tanah pucuk (top soil) yang banyak mengandung bahan organik dikupas dengan menggunakan bulldozer. Lapisan tanah pucuk didorong dan dikumpulkan pada lokasi tertentu, kemudian dimuat menggunakan excavator dan diangkut dengan dump truck ke tempat penyimpanan tanah pucuk. Operasi penggalian tanah penutup berupa overburden dan interburden, dilakukan dengan menggunakan excavator dan dibantu dengan bulldozer.

Ketiga, Rencana Penambangan Batubara (CoalGetting). Kegiatan penambangan batubara dapat menggunakan metode tambang terbuka (surface mining) dan tambang dalam atau tambang bawah tanah (underground mining). Tambang terbuka (surface mining) adalah metode penambangan yang segala kegiatan atau aktifitas penambangannya dilakukan di atas atau relatif dekat dengan permukaan bumi, dan tempat kerjanya berhubungan langsung dengan udara luar. Sementara tambang dalam atau tambang bawah tanah (underground mining) adalah metode penambangan yang segala kegiatan atau aktifitas penambangannya dilakukan di bawah permukaan bumi, dan tempat kerjanya tidak langsung berhubungan dengan udara luar.

Keempat, Pengangkutan Batubara. Batubara yang dihasilkan dari aktivitas operasional tambang diangkut langsung ke stockpile yang kemudian akan diangkut kembali atau dikapalkan kepada end user.

Kelima, Kegiatan Utilitas. Untuk menunjang kegiatan pertambangan batubara, maka disamping menggunakan berbagai fasilitas yang sudah ada saat ini juga akan dibangun fasilitas dan infrastruktur 
tambang baru, antara lain: jaringan jalan, mess karyawan, pembangkit tenaga listrik, penyediaan air, dan lain-lain.

Keenam, Pelaksanaan Program Community Development. Pelaksanaan program comdev adalah upaya pemberdayaan masyarakat atau lebih dikenal dengan sebutan comdev adalah bagian dari kelola lingkungan sosial yang merupakan bagian dari visi-misi perusahaan dalam upaya mewujudkan tanggung jawab sosial dalam kerangka Corporate Social Responsibility (CSR) yang tepat, terpadu dan berkesinambungan. Program ini memiliki tujuan untuk mendorong prakarsa, inisiatif dan semangat keswadayaan masyarakat untuk mengembangkan kapasitas sumberdaya manusia serta kemampuan masyarakat kampung dalam mengelola dan memanfaatkan potensi sumberdaya alam dan lingkungannya secara berkelanjutan.

Ketujuh, Reklamasi dan Revegetasi Lahan Bekas Tambang. Reklamasi dan revegetasi lahan bekas tambang merupakan salah satu kewajiban yang penting pada usaha pertambangan batubara. Tahapan, prosedur dan mekanisme pelaksanaan kegiatan reklamasi dan revegetasi lahan bekas tambang mengacu dan berpedoman kepada ketentuan yang berlaku serta arahan teknis dari Dinas Pertambangan.

Pada tahapan Pasca Operasi terdapat beberapa kegiatan, antara lain: Pertama, Pelepasan Tenaga Kerja (PHK). Ketika sebuah tambang batubara berakhir masa umur tambangnya, maka aktivitas penambangan batubara memasuki tahap akhir, dan keadaan ini membawa implikasi dan konsekuensi logis bagi Manajemen Perusahaan untuk melakukan rasionalisasi tenaga kerja (PHK) atau pelepasan tenaga kerja. Rasionalisasi atau pelepasan tenaga kerja merupakan hal yang wajar terjadi pada setiap kegiatan proyek yang memasuki tahap akhir operasi. Yang perlu dicermati adalah dalam proses dan tatacara rasionalisasi tersebut harus dikelola dengan baik, berpedoman kepada ketentuan hukum yang berlaku dan mengedepankan komunikasi yang baik antara Manajemen dengan setiap karyawannya.

Kedua, Pengelolaan Kolam Terakhir Reklamasi Lahan Bekas Tambang. Dengan penerapan sistem tambang terbuka pada pola penambangan terbuka yang akan digunakan pada operasi penambangan batubara, diperhitungkan pada akhir umur tambang akan terbentuk satu kolam terkahir bekas bukaan tambang (pit) yang perlu dilakukan rehabilitasi atau reklamasi sesuai ketentuan tentang reklamasi lahan bekas tambang. Desain pengelolaan kolam terakhir reklamasi lahan bekas tambang ini berbeda dengan desain pada kegiatan reklamasi dan revegetasi pada kolam-kolam bekas tambang sebelumnya, dengan pertimbangan keterbatasan material tanah penutup yang dapat digunakan untuk reklamasi-revegetasi. Desain rancangan pengelolaan kolam terakhir ini diarahkan pada upaya pemulihan secara vegetatif, sipil-teknis, pengaturan landscap dan tekniksilvikultur yang memungkinkan terbentuknya satu desain kolam terakhir yang memiliki multi-manfaat, diantaranya sebagai area rekreasi (wisata alam danau buatan), area terbuka hijau yang dapat difungsikan sebagai wahana pendidikan lingkungan bagi pelajar, sebagai cadangan sumber air (reservoar), serta pengembangan usaha budidaya ikan air tawar.

Setelah PT. A mendapatkan Kuasa Pertambangan Eksploitasi seluas seluas 2.500 (dua ribu lima ratus)

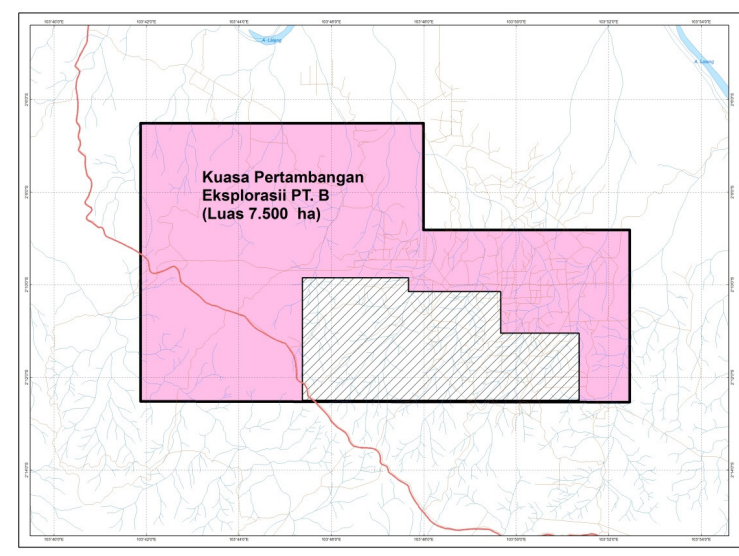

Gambar 4. Peta Permohonan Kuasa Pertambangan Ekplorasi PT. A Seluas $7.500 \mathrm{Ha}$

Ha, terdapat sisa areal seluas 7.500 (tujuh ribu lima ratus) Ha, selanjutnya akan dimohon kembali oleh group perusahaan dengan menggunakan nama PT. B. Selanjutnya PT. B mengajukan Kuasa Pertambangan Eksplorasi dari sisa areal seluas 7.500 (tujuh ribu lima ratus) Ha, sebagaimana Gambar 4.

Setelah mendapatkan Kuasa Pertambangan Eksplorasi seluas 7.500 (tujuh ribu lima ratus) $\mathrm{Ha}$ tahap selanjutnya adalah PT. B melakukan kegiatan eksplorasi batubara terhadap areal seluas 7.500 (tujuh ribu lima ratus) Ha. Penjelasan tahapan kegiatan eksplorasi batubara telah penulis jelaskan pada bahasan sebelumnya. 
Tahap selanjutnya adalah PT. B mengajukan permohonan peningkatan status Kuasa Pertambangan dari Eksplorasi menjadi Kuasa Pertambangan Eksploitasi. Areal yang dimohon ini adalah sebagian areal prospek yang memiliki kandungan batubara yang didapat dari kajian tahapan ekplorasi sebelumnya. Adapun areal yang dimohon Kuasa Pertambangan Eksploitasi tidak boleh melebihi luas maksimal yaitu 5.000 (lima ribu) Ha. PT. B menganggap areal yang memiliki potensi cadangan batubara adalah seluas 2.500 (dua ribu lima ratus) Ha. Oleh karena itu, PT. B mengajukan permohonan Kuasa Pertambangan Eksploitasi untuk areal seluas 2.500 (dua ribu lima ratus) Ha, sebagaimana dalam Gambar 5.

Setelah PT. B mendapatkan Kuasa Pertambangan Eksploitasi pada areal seluas 2.500 (dua ribu lima ratus) Ha, selanjutnya akan dimohon kembali oleh perusahaan dengan menggunakan nama PT. C. Selanjutnya PT. C mengajukan Kuasa Pertambangan Eksplorasi dari sisa areal seluas 5.000 (lima ribu) Ha, sebagaimana Gambar 6.

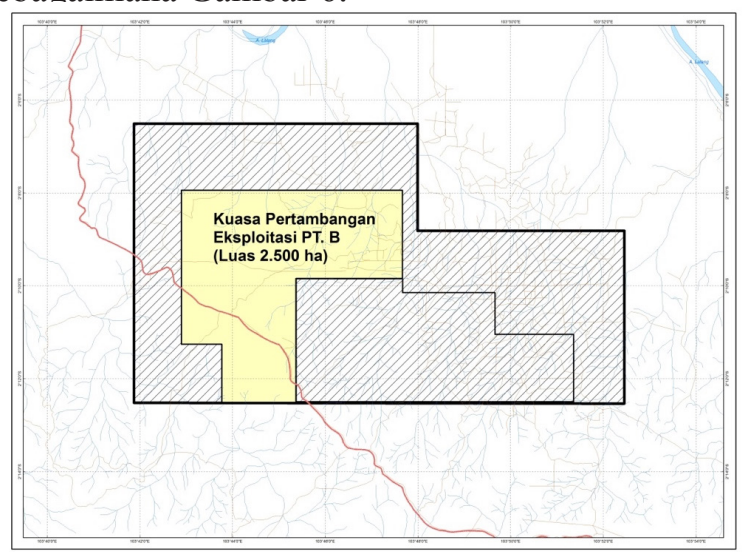

Gambar 5. Peta Permohonan Kuasa Pertambangan Ekploitasi PT. B Seluas $2.500 \mathrm{Ha}$

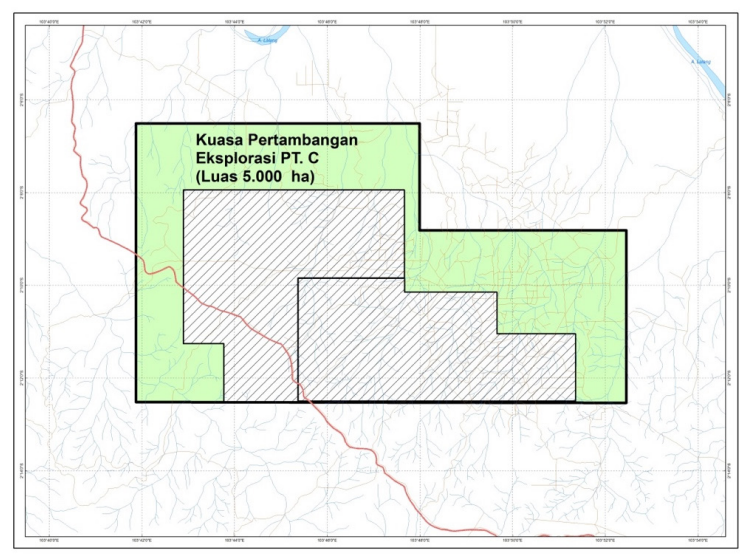

Gambar 6. Peta Permohonan Kuasa Pertambangan Eksplorasi PT. C Seluas 5.000 Ha

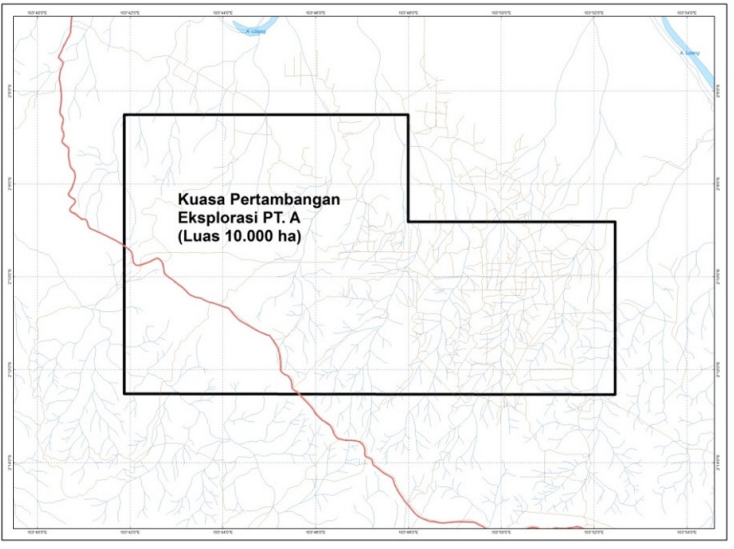

Gambar 7. Perusahaan Awal

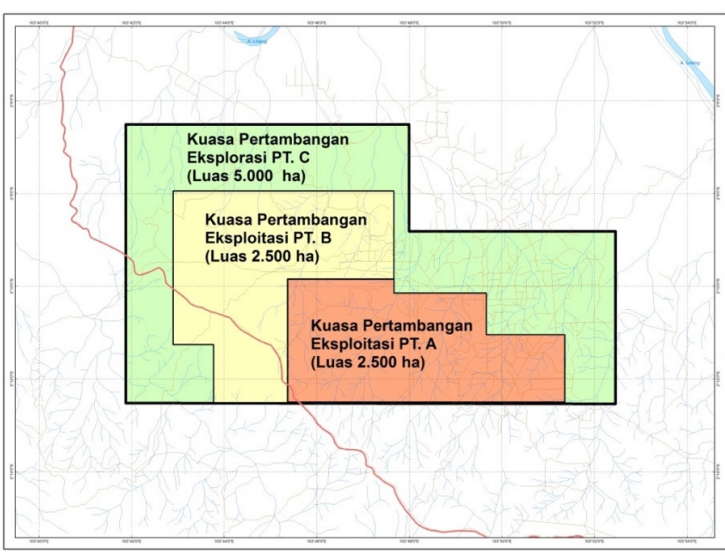

Gambar 8. Perusahaan Akhir

Demikian terus selanjutnya. Dengan demikiaan, dapat digambarkan bahwa berawal hanya dari satu perusahaan yaitu PT. A dapat dikembangkan menjadi 3 perusahan, yaitu PT. A, PT. B, dan PT. C, sebagaimana Gambar 7 dan 8.

Setelah diterbitkannya Undang-Undang No. 4 Tahun 2009 tentang Pertambangan Mineral dan Batubara, maka terjadi penyesuaian nama yang sebelumnya Kuasa Pertambangan Penyelidikan Umum, Kuasa Pertambangan Eksplorasi, dan Kuasa Pertambangan Eksploitasi dirubah menjadi Izin Usaha Pertambangan Eksplorasi (IUP Eksplorasi) dan Izin Usaha Pertambangan Operasi Produksi (IUP OP). Tahapan Penyelidikan Umum menjadi satu bagian dari Izin Usaha Eksplorasi.

\section{PENUTUP}

\section{Kesimpulan}

Pelaksanaan ekspansi perusahaan group yang terjadi di sektor pertambangan. Setidaknya terdapat empat cara yang digunakan oleh perusahaan dalam melakukan ekspansi di sektor pertambangan batubara. 
Adapun cara yang dilakukan oleh perusahaan dalam melakukan ekspansi adalah sebagai berikut: membentuk Perusahaan Baru. Perusahaan yang ingin berusaha di dalam sektor pertambangan batubara harus mengajukan IUP. IUP ini merupakan legalitas utama yang diperlukan. IUP dibagi menjadi 2 (dua), yaitu: Pertama, IUP Eksplorasi. Diberikan oleh pemerintah kepada perusahaan dengan luas maksimal 50.000 (lima puluh ribu) hektar. Kedua, IUP Operasi Produksi. Diberikan oleh pemerintah kepada perusahaan dengan luas maksimal 15.000 (lima belas ribu) hektar. Pemberian IUP tersebut telah sesuai dengan Undang-Undang No. 4 Tahun 2009 tentang Pertambangan Mineral dan Batubara.

\section{Rekomendasi}

Sebagai komoditi energi yang bernilai strategis bagi kepentingan nasional, seharusnya ada peraturan perundang-undangan yang mengatur khusus mengenai perusahaan group dalam pengusahaan pertambangan batubara. Khususnya yang mengatur tentang pembatasan luas lahan atau jumlah izin usaha maksimal yang bisa dimiliki oleh satu badan usaha dan satu group berusahaan. Dengan demikian, pengusahaan pertambangan batubara tidak hanya dikuasai oleh group perusahaan yang memiliki modal kapital yang besar. Sebagai contoh, sektor kehutanan mempunyai peraturan perundang-undangan khusus bagi perusahaan group dalam pemanfaatan hasil hutan kayu, yaitu Peraturan Menteri Kehutanan No. P.S/Menhut-II/2014 tentang Pembatasan Luasan Izin Usaha Pemanfaatan Hasil Hutan Kayu (IUPHHK) Dalam Hutan Alam, IUPHHK Hutan Tanaman Industri Atau IUPHHK Restorasi Ekosistem Pada Hutan Produksi. Dalam Pasal 5 peraturan tersebut dijelaskan bahwa IUPHHK-HA, IUPHHK-RE atau IUPHHK-HTI dapat diberikan paling luas 50.000 (lima puluh ribu) hektar dan paling banyak 2 (dua) izin untuk 1 (satu) perusahaan atau untuk 1 (satu) induk perusahaan. Selain sektor kehutanan, sektor perkebunan juga memberikan batasan bagi perusahaan group dalam mengusahakan hasil perkebunan, yaitu Peraturan Menteri Pertanian No. 98/Permentan/Ot.140/9/2013 tentang Pedoman Perizinan Usaha Perkebunan, Pasal 17 peraturan tersebut menjelaskan bahwa Izin Usaha Perkebunan untuk 1 (satu) perusahaan atau kelompok (Group) perusahaan perkebunan diberikan dengan batas paling luas berdasarkan jenis tanaman.

\section{DAFTAR PUSTAKA}

\section{Peraturan Perundang Undangan:}

Undang-Undang Nomor 40 Tahun 2007 tentang Perseroan Terbatas, Lembaran Negara Tahun 2007 Nomor 106, Tambahan Lembaran Negara Nomor 4756.

Undang-Undang Nomor 23 Tahun 2014 tentang Pemerintah Daerah, Lembaran Negara Tahun 2014 Nomor 244, Tambahan Lembaran Negara Nomor 5587.

Peraturan Pemerintah Nomor 23 Tahun 2010 tentang Pelaksanaan Kegiatan Usaha Pertambangan Mineral dan Batubara.

Peraturan Pemerintah Pengganti Undang-Undang (Perppu) Nomor 2 Tahun 2014.

Peraturan Menteri Negara Agraria/Kepala BPN Nomor 2 Tahun 1999 tentang Izin Lokasi.

\section{Buku:}

Irwandy, Arif, 2014, Batubara Indonesia, Jakarta: Gramedia Pustaka Utama.

D. Bailey, Kanneth, 1982, Methods of Social Research, New York: A Division of Macmillan Publishing Co. Inc.

Kansil dan Cristine, 1995, Hukum Perusahaan Indonesia, Jakarta: Pradnya Paramita, Jakarta.

Murjianto R., 2002, Pengantar Hukum Dagang: Aspek-aspek Hukum Perusahaan dan Larangan Praktek Monopoli, Yogyakarta: Liberty.

Neuman, W. Lawrence, 2003, Social Research Methods (Qualitative and Quantitative Approaches), Ed. $5^{\text {th }}$. Boston: Allyn and Bacon. Pusat Sumber Daya Mineral Batubara dan Panas Bumi, Executive Summary Pemutakhiran Data dan Neraca Sumber Daya Energi Tahun 2015.

Riyanto, Bambang, 1999, Dasar-dasar Pembelanjaan Perusahaan, Edisi Keempat. Yogyakarta: BPFE. Simanjuntak, Emmy Pangaribuan, 2008, Hukum Perusahaan Kelompok dan Globalisasi Usaha (Concern), Bahan Ajar Mata Kuliah Hukum Dagang Internasional, Yogyakarta: Universitas Gadjah Mada.

Soekanto, Soerjono dan Sri Mamudji, 1985, Penelitian Hukum Normatif Suatu Tinjauan Singkat, Jakarta: Rajawali Pers. 
Sulistiowati, 2010, Aspek Hukum dan Realitas Bisnis Perusahaan Group di Indonesia, Jakarta: Erlangga.

, 2011, "Limited Liability dalam Limited Liability pada Konstruksi Perusahaan Kelompok Piramida", Mimbar Hukum, Volume 23, Universitas Gadjah Mada.

\section{Website:}

National Institute of Statistics and Economic Studies, Group of companies, diakses dari: http://www.insee.fr/en/methodes/default. asp? page $=$ definitions/group -societesentreprises.htm pada tanggal 2 Juli 2017.

The South African Institute of Chartered Accountants (SAICA), The Definition of a Group of Companies as per The New Companies Act has Changed, diakses dari: https://www.saica. co.za/tabid/1444/itemid/1784/The-definitionof-a- group -of-companies-as- per-the.aspx. pada tanggal 1 Juli 2017. 